\title{
The Case of "Jane and Joe": A Diary-Based, Cross-Contextual Case Study
}

\section{THOMAS MACKRILL ${ }^{a}$}

${ }^{\mathrm{a}}$ University of Aarhus, Aarhus, Denmark

b Correspondence concerning this article should be addressed to Thomas Mackrill, Æblehaven 2, 3450 Allerød, Denmark.

Email: T thomas@life-change.dk

\begin{abstract}
This case study of the client "Jane" seen by the therapist "Joe" is an unpublished part of my dissertation (Mackrill, 2008). Jane's presenting problems included: (1) memories that bother her on a daily basis, and Jane's sense of vulnerability in relation to these; (2) Jane's experience of being very sensitive; (3) Jane's low self-esteem; and (4) Jane's insecurity with regard to close relationships with men. Joe's theoretical orientation in treating Jane was humanistic and existential. The case study is based on (a) diaries that the client and therapist wrote after each session, (b) recordings of the 12 therapy sessions, and (c) feedback from Jane and Joe on initial drafts of the case study. In the first few pages of the case study Mackrill identifies the concepts he utilized in organizing the data. These are based on a contextual view of behavior. In order to understand change in therapy one must look at the client's behavior and experiences across life contexts (Dreier, 2008). Specific organizing concepts utilized in writing up the case included focusing on the client's point of view in different contexts; the difference among points of view of the participants; and identifying shifts in perspective when they occurred. The write-up steered clear of an analysis in terms of theoretical mechanisms of change based on any particular theory of psychotherapy, such as cognitive-behavioral, existential, or psychodynamic. The methodology behind this case is presented in Mackrill (2011).
\end{abstract}

Key words: psychotherapy, counseling, diaries, adult children, everyday life, cross-context theory, phenomenology, sense of agency, case studies, clinical case studies

\section{OUTLINE OF THE CASE}

- Introducing a case

- Notes

- The basic theoretical framework

- Difference

- Shift

- Cross-contextual

- A complexity of concerns

- From daring to be open - to being a private person.

- Not being afraid.

- Using friends and relations 
- The search for an I-focus.

- Trying new points of view out

- Cruel is sometimes right

- Receiving care

- The rear view mirror

- Too sad

- Joe's theory of grief

- Representing the future

- Joe's theory of sharing

- Finding a good man - investigating more topics

- Bearing a grudge

- The sluices open.

- The men in Jane's past

- Disentangling the good and the bad stuff

- Back to intimate relationships

- I am not the same as you

- Understanding a life with alcohol and drugs.

- Validation

\section{INTRODUCING A CASE}

I will use the case of Jane and Joe to introduce my concepts. First I will very briefly introduce the case. After the case and the concepts have been introduced, the case will be analysed in more depth.

Jane, the client, is a 28-year-old university student. In his notes from the referral session, Joe, the therapist, writes the following,

'Jane's mother has been an alcoholic and a drug addict as long as Jane can remember. Her father lived with the family until Jane was 5 years old. Thereafter, they only kept in touch by phone and this also stopped when Jane was 13 years old. There was a lot conflict and violence in the home, so the father's moving was a relief. Jane has a brother, who is three years younger than her. When Jane was 10 years old, her mother moved the family to V-town, where she came from, and the substance abuse escalated, while the number of [her mother's] more or less suspect boyfriend's increased. A couple of years later, her mother lived with a violent and psychopathic man and her mother was given the choice between having her children taken into care against her will or voluntarily. She chose the latter. Jane describes her and her brother as rescued by the children's home. They were there for a year and a half until the mother took more charge of her life. This didn’t mean she stopped drinking or taking drugs. (Jt page 1§2-5)

Jane left home when she was 17 years old and moved to a University town at the age of 20. This information does not correspond with Joe's referral notes. Jane has kindly agreed to validate drafts of this analysis. Her comments are incorporated in this text. 
The Case of "Jane and Joe": A Diary-Based, Cross-Contextual Case Study

Mackrill

Pragmatic Case Studies in Psychotherapy, http://pcsp.libraries.rutgers.edu

Volume 7, Module 1, Article 11, pp. 187-229, 02-28-11 [copyright by author]

\section{NOTES}

The following text refers makes referrals to empirical data. After each of a series of therapy sessions, the client and the therapist write journals of significant events in the session and their thoughts on why these events are significant. Jane's journal is coded J1, J2 etc. Joe's journal is coded Jt1, Jt2 etc. The numbers refers to the session number, after which they are writing. In this way, it is possible to see who is writing and where in the series of sessions the quotation originates. There are 12 sessions and Joe's notes concerning the referral session are also quoted.

Prior to each new session, Jane also writes a log concerning extra-therapeutic change events that she has experienced between sessions. She is asked to describe events that she experiences as new or different in some way, as she moves from place to place in her everyday life away from the therapeutic setting. These logs are coded J1a, J2a etc. Once again the numbers refer to the previous session.

\section{THE BASIC THEORETICAL FRAMEWORK}

Prior to analysis, I will clarify my definitions of the concept point of view ${ }^{1}$ and concern. Both concepts are related to understanding human action as contextual. As human beings, we move across contexts from place to place. Contexts are the different specific settings in which human beings live and participate with others. Contexts in Jane's life are, for example: at home where Jane may write her journal or have friends or relations visiting, other peoples' homes where they live (mother's home, brother George's home, friends' homes), the university, cafés or other places where dates are held, therapeutic sessions with Joe, other treatment sessions with other health workers etc.) Jane moves physically and mentally between contexts making sense of her life in the pursuit of a complexity of concerns including among other concerns, understanding her emotional life, attaining a university degree, and finding 'a good man'.

Our concerns and points of view are contextual in nature. Our points of view are not merely understood as some form of intra-psychic life or schemata that is put into action. Our points of view are related to how we position ourselves physically, as we move about. For example, standing on a ladder gives a different point of view than kneeling down. Looking through a keyhole at people offers a different point of view than entering the room and shaking their hands. Our contextuality is, however, not just a matter of our present physical context. It also has to do with our movement between contexts. Where we come from (move from) and where we are heading are important parts of our present contextuality. As Jane moves across contexts, she pursues a complexity of concerns. She views her contexts through these concerns. Jane, for example, as a single woman hoping to find a man, views men in this light. This follows the notion that the world appears to us as possibilities. Jane also views men in the light of past contexts (where she is coming from). Just as she views men in the light of her actual position in present contexts. Thus, our points of view are connected with our movements from place to place. In a way, the connection between our concerns and our contextuality is clear in the English expression point of view. The term point of view captures the fact that we position

\footnotetext{
${ }^{1}$ In the methodology paper (Mackrill, 2011), the term stance is employed instead of point of view.
} 
The Case of "Jane and Joe": A Diary-Based, Cross-Contextual Case Study

Mackrill

Pragmatic Case Studies in Psychotherapy, http://pcsp.libraries.rutgers.edu

Volume 7, Module 1, Article 11, pp. 187-229, 02-28-11 [copyright by author]

ourselves or are positioned in one of various possible positions that are accessible to us as we move about from place to place in the pursuit of concerns. Some doors are locked. Some doors are open. Some locked doors can be opened, both physically and mentally. The point made here once again is that our physical and mental stances are connected and are not separate issues. They are connected as we move from place to place in the pursuit of our concerns. We live contextual lives. We are not just 'beings-in-the-world'. We are particular human beings with particular histories and concerns in the living room, on the sofa, in the office, down the pub, with particular others or alone. We are 'on the way from' and 'on the way to' and we are present.

Our points of view are related to how we position ourselves or are positioned among accessible points of view, and how we move and have moved within the contexts of our lives and from context to context, and how we see ourselves moving in the future, i.e. our direction (our concerns). We develop our points of view in our lives, as we pursue concerns moving from context to context engaging in a complexity of intersubjective meetings. We are always participating with others, whether we choose to do so by looking through keyholes or shaking hands. These are just different ways of participating. We are many human beings all intermingling and participating in various ways in the pursuit of concerns across time and place. We position ourselves in relation to the points of views of others. We experience other people taking stances, i.e. positioning themselves physically and with regard to subjective stances taken. In these intersubjective meetings new points of view become accessible to us. Thus, concerns, points of view and positioning across time and place and intersubjective meetings are interrelated concepts in this analysis.

As the following analysis shows, points of view are not just represented by people. Contexts, for example, such as the therapeutic room also represent points of view, but let us return to this matter later as the analysis progresses.

The following analysis examines differences and shifts in point of view, relating these to Jane's movements across contexts and through time. Jane and Joe's perspectives are accessed via their two journals. Recordings of sessions have been listened to, to correlate findings, and analyses have been returned to Joe and Jane for validation and comment. These comments are incorporated in this text.

The fact that access to contexts is via journals, via what is said in therapy sessions and via participant validation is epistemologically significant. Client contexts are thus examined as meaning structures as presented by therapists and clients.

Differences in perspectives between participants are examined and individual differences in perspective are also highlighted.

\section{DIFFERENCE}

This analysis focuses on the differences in point of view between the participants in Jane's life. Jane's points of view encompass her concerns. Let us look at an example. Jane is concerned 
The Case of "Jane and Joe": A Diary-Based, Cross-Contextual Case Study

Mackrill

Pragmatic Case Studies in Psychotherapy, http://pcsp.libraries.rutgers.edu

Volume 7, Module 1, Article 11, pp. 187-229, 02-28-11 [copyright by author]

about reducing sadness J1§3), Jane expresses the point of view that she is too sad, and not able to 'forgive and forget' (J1a§4,J7a§1).

'It would be great if I could let go of these things which keep turning up. Something like "forgive and forget" [written in English tm] and get on with my life.' (J7aß1)

Jane also has the point of view that she needs help to 'accept or forgive' (J1§3, J6§1). Jane seems to move between trying to accept and trying to forget. She moves between points of view and notes,

'I believe I need help to accept or forgive, or whatever it is it takes so I can live and be happy together with and in spite of my emotional baggage.' (J1§3)

Joe, the therapist, has another concern. He views Jane's sadness in relation to the past as grief, which involves grieving (Jt6§5). This involves remembering and sharing. They have differing point of view concerning the same issue. Jane initially wants to rid herself of certain experiences and Joe wants access to these experiences. The intersubjective meeting is a meeting of these points of view.

Points of view do not have to be expressed in words. Differences can be expressed in ways of being. An example of this is when Jane notes that Joe smiled in an approving [anerkendende] way when she cried in a previous session, noting that she understood that he felt 'ok'. Joe's point of view, as understood by Jane, was significant (J1aß1). If she had experienced Joe as 'not approving' and not 'ok', the meeting would have been different. Jane understood what she saw, as a confirmation that Joe's point of view in this situation was that crying here was ok. Intersubjective meetings are not necessarily understood as a meeting of opinions that are expressed verbally.

As we will see, Joe often expresses points of view that act as a foil to Jane's own points of view. Joe also expresses points of view vicariously for Jane, where Jane does not seem to have a point of view. This also challenges Jane. Examples of this will be presented later. Let us return to our example of a difference.

Jane expresses the point of view that sadness is something that she or Joe in some way should help her alleviate by helping her forgive and accept or forget. Jane experiences her continuing to feel sad about the past as 'bearing a grudge'(J7a§1), thus her sadness and anger (the anger is revealed later in the logs (J6a§1, J8§1)) has a negative connotation for Jane. Joe's point of view is different. Joe relates sadness to what happens in one's life. He introduces the term, grief. He constantly seeks out connections between Jane's sadness and her life contexts in the present (e.g. Jt4§1, where Joe focuses on Jane's sadness when she finds her date was not right for her), her past (e.g. J6a§1, where Joe notes that Jane has not experienced being childish and unconcerned in her childhood), and her hopes for the future (e.g. J7§1, where Joe connects Jane’s sadness with her desire to have a family).

For Joe, grieving successfully involves sharing and confiding (Jt11§3) He notes that, 'you can live your way through grief' [lit. det kan gennemleves](Jt6§8) This is a far cry from Jane's 
The Case of "Jane and Joe": A Diary-Based, Cross-Contextual Case Study

Mackrill

Pragmatic Case Studies in Psychotherapy, http://pcsp.libraries.rutgers.edu

Volume 7, Module 1, Article 11, pp. 187-229, 02-28-11 [copyright by author]

forgiving and forgetting, but perhaps closer to Jane's point of view concerning forgiving and accepting. During the course of sessions Jane gets sadder as Joe continuously points out the connections between the sadness and Jane's life situations. This challenges Jane as she experiences a failure in the pursuit of her concern of becoming less sad. However, in the long run, Jane does experience that her memories affect her to a lesser extent (J9a§1).

This is an example of a difference in point of view. It shows how the difference in points of view may be therapeutically fruitful. I hope now, I have made the concept of a difference in point of view clear. This is an analysis of different points of view and thereby different concerns.

\section{SHIFT}

This analysis also involves tracing shifts in points of view through the course of the logs. I will be looking at shifts in Jane's points of view. Let us look at the previous example once again as a possible shift. I have already noted Jane's initial point of view, of wanting to become less sad by forgiving and forgetting or accepting. Later in her logs, Jane begins to consider Joe's point of view concerning grief. Jane (J6a§1) notes how she doesn't really grieve, as Joe suggests. She usually 'tries to push the pictures away and think of something else' (J6a§1). Nor does she share and confide as Joe suggests, but prefers to keep things to herself (J5§2). From the following logs (J8, J8a, J9a, J10), it becomes clear that Jane's point of view has shifted. She now chooses to confide in Joe and shares a series of traumatic experiences and stays with her sad memories both in the therapy sessions and in her life outside, rather than pushing them away. It is not the case that Jane hasn't told Joe about a traumatic event earlier. Actually she told him about one in the first session (Jt1§3). Unlike Joe, however, Jane does not register this as significant in her first logs (J1 \&J1a). This may suggest that Jane gives telling others about traumatic events more significance as her therapy proceeds. She first works systematically with traumatic incidents later on in her therapy (J8, J8a, J9a, J10). This is apparent as Jane writes about traumatic events in her journal and Joe notes that they talk about these incidents. Thus Jane practises the point of view that she might originally have called acceptance and that Joe calls grieving. This is an example of a shift - a shift from being caught between accepting and forgetting to staying with, sharing and confiding and to use Jane's original word, accepting. Jane, however, does not continue to use the word 'accepting' to understand her point of view. She begins to use Joe's term grief (J6a§1, J6§2) Interestingly, after the shift in point of view, there is a temporary increase in the amount of traumatic material present in Jane's consciousness. This may be connected with the fact that she now has a way of dealing with the traumatic memories. The intrusive memories later subside (J9a§1). This helps Jane with her difficulty in falling asleep, as she often experienced intrusive traumatic memories, when trying to sleep. Once again, this suggests that differences in point of view may play a part in a shift in point of view and therapeutic change.

Some shifts also take place prior to the first session. Some of these will be mentioned in the following analysis. Jane mentions a shift as part of what brings her into therapy in the first place. Jane tells Joe that she used to be a 'tough cookie' [en hård negl], and now 'her feelings take up a lot of space’ (Jt4§5). Jane is clearly looking for help in dealing with this transformation. 


\section{CROSS-CONTEXTUAL}

The analysis also involves investigating these differences and shifts across contexts. As we will see Jane's therapy involves a whole series of contexts. Examples of contexts are as previously mentioned: at home where Jane ponders her life situation, writes her diary, has friends or relations visiting; other peoples' homes (mother's home, brother George's home, friends' homes), the university; cafés where dates are held; the therapy room, where she meets with Joe). Jane's life is not just lived across present contexts. Past and potential future contexts are also part of her consciousness. She is 'on the way from' and 'on the way to' and in the present. Jane lives in space and time. She moves through specific spaces/contexts across time in the pursuit of concerns, participating in contexts with others and trying to make sense of the experience.

Let us briefly look at an example of the cross-contextual nature of Jane's therapy. Once again the experience of being too sad will be taken as a theme. Jane writes (J5a) the story of what brought her into therapy in the first place. It is a story about the chronic headaches that Jane has suffered since she was a child, that still trouble her. It emerges, that a series of experts have failed to find the cause of her headaches or a cure for them. Immediately before contacting TUBA, Jane has seen a neurologist who could not find a physical cause for her headaches and this led Jane to conclude both that there was something 'wrong with her head' (J5a§2) and that she was in a terrible state [lit. helt til rotterne $=$ completely to the rats tm] (J5a§2). Let us look at what Jane writes

When she [the neurologist tm] was satisfied that nothing was wrong with me, she started inquiring when the headaches had begun. I think I already had tears in my eyes at this point and it didn't take her long to find out my childhood was a mess, that my mother drank, and that I had not 'talked to anyone about it'. She was very nononsense and abrupt, when she said that she definitely thought I should go and see a psychologist and if I did not want to do this, she could write a prescription for antidepressants for me. I refused the medicine, but I was completely bowled over and cried all the way home. I can't see myself as ‘one of those people' who takes antidepressants. It is not a thought I can reconcile myself with in any way. My mother needed her medication (which was alcohol and drugs) so daily life could make some form of sense. I would like to believe that I have come further in my life than being dependent on a substance to feel good. A week later in October, I had my first session at TUBA. (J5a§2)

According to Jane, the neurologist presented her with a choice between seeing a psychologist or taking antidepressants. Jane chose to see a therapist and contacted TUBA ${ }^{2}$. When Jane starts in therapy she is concerned as to whether there is something intrinsically 'wrong' with her'. She wonders whether she is 'completely to the rats' (using the figurative Danish expression) like her mother. Jane also writes about herself in a similar way in her initial log (J1) where she describes her problems as she sees them. Jane notes that she feels she is tired of thinking about the past (§3). She would like to be able to talk about her childhood experiences without getting sad (§3). She needs help to live and be happy together with, and in spite of, her emotional baggage (§3). She needs help to forgive and accept (§3). She must become better at being open and trusting (§4), and she notes that in her looking for a good man she must become better at not being afraid (§4). Summing up, it is clear that she experiences herself as problematic in a whole series of ways. She sees herself as too sad, not happy enough, not forgiving enough, not accepting

${ }^{2}$ A counselling service for young persons from families with alcohol problems. 
The Case of "Jane and Joe": A Diary-Based, Cross-Contextual Case Study

Mackrill

Pragmatic Case Studies in Psychotherapy, http://pcsp.libraries.rutgers.edu

Volume 7, Module 1, Article 11, pp. 187-229, 02-28-11 [copyright by author]

enough, not open enough, not trusting enough and too afraid of men. She is clearly saying that she should be different, suggesting 'I am not as I should be'. In a whole series of ways she presents herself as wrong. 'Wrong' is not a term Jane generally employs. However in log 5a, Jane, in retrospect, notes her former fear that 'something must have been wrong [galt] with my head' (J5a§2) and she discovers she is not 'a hopeless case’ (ikke fuldstændigt tabt bag en vogn] (J5a§4). I use the term wrong to sum up a series of points of view, that Jane initially expresses concerning her self. Jane initially implies that if she were different, less sad, happier, more forgiving and accepting, more trusting and more courageous, then things would be better. In some way, this would be more right. This initial expression of not being as she should be, or being 'to the rats' is first put into context in the fifth log, where Jane presents her treatment history. Implicitly she implies that Joe, the therapist in some way might be able to deal with her being too sad, not happy enough, not forgiving enough, not accepting enough, not open enough, not trusting enough and too afraid of men. She is implying that he should help make her right, even though she does not use the term right. What Jane writes seems to suggest that she wants to be able to control her emotional responses in specific situations, for example when she experiences intrusive memories and when she is in the company of men.

The course of psychotherapy is one course of treatment that Jane is trying among many treatments available. Joe gathers, from the referral session, that Jane has previously seen a psychotherapist, but didn’t feel this helped (Jt page.1§10). During the course of the therapy, Joe discovers that a cranial massage therapist is treating Jane while she is in therapy with him (Jt6§3). Jane notes $(\mathrm{J} 5 \mathrm{a} \S 2,4)$ how she has been through a series of treatments and tests for her chronic headache, various types of massage, doctors and the psychotherapist, that haven't helped. Jane writes

Regarding the headache, after finishing a course of treatment at a chiropractor, I have started seeing a cranial massage therapist, (whose motto is: it doesn't have to hurt to get better). I hope that this combined with the sessions with the therapist will have a favourable effect by hopefully loosening up physical as well as psychological tension. (J5a§4)

There seems to be a connection between how Jane presents herself and her problems in the initial sessions and Jane's previous treatment experiences in other contexts, including the meeting with the neurologist. The shift in her perspective is first made clear in the fifth log. Let us see look at Jane's words.

A week later [after seeing the neurologist tm] in October, I had my first session at TUBA. In the period that has gone by since, I have got over the shock and am no longer afraid of being ' beyond help' [uden for pædagogisk rækkevidde]. I can see from the life I have created for myself, that I am not a hopeless case [ikke fuldstændig tabt bag en vogn] $(\mathrm{J} 5 \mathrm{a} \S 3,4)$.

Jane notes how she now has 'got over the shock' after seeing the neurologist and she is no longer afraid of being 'beyond help' (J5a§4) and is thereby now convinced that she does not need drugs to feel good, as her mother does. Thus, when Jane originally presents herself as being wrong and needing putting right, it is crucial that Joe doesn’t just accept this concern and start trying to put her right. From the data, I cannot conclude that Jane didn't feel wrong in some way before meeting the neurologist or other health workers. But it seems fair to suggest that the visit at the 
The Case of "J ane and J oe": A Diary-Based, Cross-Contextual Case Study

Mackrill

Pragmatic Case Studies in Psychotherapy, http://pcsp.libraries.rutgers.edu

Volume 7, Module 1, Article 11, pp. 187-229, 02-28-11 [copyright by author]

neurologist did not alleviate her feeling wrong in any way, if anything it added to the sedimentation of this point of view.

The adopted point of view of wrongness is continuously undermined by Joe's constant investigations of the connections between Jane's subjective emotional state and her life conditions. Joe reveals a point of view that life conditions and subjective emotional state are connected. Joe's point of view is expressed in his examination of connections between Jane's emotional state and her life contexts, past, future and present. This investigation supports Jane's own questioning as to whether anything is wrong with her.

Jane is engaged in her own analysis that she shares with Joe and us in her journal to various degrees. In log J6a§1, Jane calls this her 'own little analysis'. Even though Jane humbly refers to her own analysis in this way, Jane's analysis is the key to her therapy. Jane consistently uses the diary to analyse her life. Analysis is not just something that takes place in the therapy sessions with Joe. She does this in many contexts. She uses the diary to make these investigations, and I will maintain that even if she did not write the journal she would try to make sense of connections in her life outside the therapy sessions, as we all try and make sense of our lives. Even though the guidelines for writing the journal suggest that Jane should write about significant events in the therapy sessions, Jane often chooses not to do so. She is clearly far more interested in investigating her life.

Let us look at an example of this (J5a§1). Jane has after the fifth session found that she feels better, but she can't understand why and Joe suggests she investigates what has happened since she started in therapy.

I have been leafing through my diary [appointment diary, not the journal for the research project. tm], to see if I could get a hint at what has happened in my 'physical' life, that is if there have been any concrete changes, that have influenced my feeling more emotionally stable now than last October [when she first contacted TUBA tm.]. I don't seem to be able see any individual incidents that might have affected my state of mind to the extent that I would have made me contact TUBA. And then again... But it is all has to do with a longer story that started way back when I started getting headaches. (J5a§1)

Jane investigates what has changed and this leads to a longer log about her life and about the headaches she has suffered since she was seven or eight. Investigating this makes her aware of why she feels better, why a shift has occurred. Thus she challenges the validity of her adopted point of view of being wrong, or 'to the rats'. The shift that has occurred is a shift from being wrong and looking to be put right, to investigating connections to make sense of what is. This says something significant about therapy. Clients may initially present concerns for treatment that are highly problematic, that may have been influenced and maintained by former client contact with health services. Joe has presented two points of view. First that there are connections between one's subjective emotional state and the contexts one is in, has been in or hopes to be in; and second that investigating these can help. This is different from Jane's initially presented point of view of expecting to be put right. The journal shows that Jane picks up on Joe's point of view already after the first session, suggesting a shift. Jane carries out her investigations in many of her life contexts. Thus, we can see that different contexts present clients with different points of view, which clients try and make sense of across contexts. Success in therapy seems to have a 
The Case of "Jane and Joe": A Diary-Based, Cross-Contextual Case Study

Mackrill

Pragmatic Case Studies in Psychotherapy, http://pcsp.libraries.rutgers.edu

Volume 7, Module 1, Article 11, pp. 187-229, 02-28-11 [copyright by author]

lot to do with whether clients can use therapeutic points of view and the points of view of other people they come across as they endeavour to make sense of their lives across contexts. Jane compares points of view across contexts and learns from these comparisons.

People (including therapists) do not just offer points of view explicitly. They also offer them by way of their actions, their ways of being. Points of view picked up in contexts, such as the therapeutic context are used to challenge points of view picked up (perhaps correctly, perhaps incorrectly) in other contexts. As we will see, the points of view therapists present are not necessarily new to clients.

I hope I have demonstrated how the concepts differences in points of view and concerns and shifts can be employed to analyse across contexts.

\section{A COMPLEXITY OF CONCERNS}

'It seems absurd. I would actually really like to find a good man and at the same time, I run as fast as I can if there is the slightest sign that a man is interested in me' (J1§4)

Jane's desire to 'find a good man' is a central concern in her therapy. Analysing all possible perspectives and concerns in any therapy is impossible. I have chosen to track several concerns through the logs. I have, however, chosen this concern as my lead research concern as it is pervasive. Jane keeps returning to it. Other pervasive concerns include Jane's desire to be less 'sad' and a wish to deal with intrusive memories from the past. These themes crop up in the analysis of the concern 'finding a good man'; just as the theme 'finding a good man' would surface if I were to track Jane's other concerns. Most of the themes in the therapy sessions are similarly intertwined in complex ways. It would also be possible to pursue therapist concerns through the logs. Pervasive therapist concerns in this case are focusing on 'sharing' and 'grieving'. If I were to extract each individual concern and track them across the logs there would be a lot of repetitions, owing to their complex intermingling. Tracking all the concerns and looking for repetitions would be an interesting task, but my desire to analyse and present multiple cases puts me in a position, where choices among many interesting possibilities have to be made. Limits must be set. So I have decided to track Jane's pervasive concern 'finding a good man' and in the course of tracking this concern, other concerns will be revealed and tracked and thus diversions will be taken.

This tracking will lead to the creation of a catalogue of points of view, differences and shifts. Features concerning the nature of differences and shifts across contexts will also be explored. This cataloguing work has already begun, with the examples given in the previous pages. In doing this I will reflect on contextual aspects of Jane's therapy, reflecting connections between contexts, past and future contexts, and present contexts, both in-session and out-of-session. I will attempt to analyse the data chronologically, well aware of the fact that this is impossible. Writing this case up is a challenge. The written text is linear, but the phenomenon described is anything but linear. Themes go off in all different directions across time and place sparking off other concerns and points of view. Thus the chronology involves tracking concerns, and then stepping back in time (or rewinding) and following other concerns that are 'picked up' or 'sparked off'. I am scratching the surface of an extremely complex phenomenon, psychotherapy. 
The Case of "J ane and J oe": A Diary-Based, Cross-Contextual Case Study

Mackrill

Pragmatic Case Studies in Psychotherapy, http://pcsp.libraries.rutgers.edu

Volume 7, Module 1, Article 11, pp. 187-229, 02-28-11 [copyright by author]

Let us now return to the initial quotation in this section. We can see that Jane is concerned with finding 'a good man'. At the same time she runs in the opposite direction, when she comes into contact with interested men. Jane finds this contradiction 'absurd', thus she hints at another concern, understanding this absurdity. This is another example of the aforementioned shift from wanting to be 'put right' to investigating connections. I will show how Jane pursues this concern in her logs, just as she pursues the concern of finding 'a good man'. The therapy session is one context among others, which she uses to make sense of her 'absurd' situation, which is a part of her striving to 'find a good man'.

\section{FROM DARING TO BE OPEN TO BEING A PRIVATE PERSON.}

We have now noted Jane's experience of wanting to find a man and running away. Jane also notes points of view about what it would take for her to find a good man. Jane writes she needs to get 'better at daring being open' (J1§4); 'better at trusting that people have her interests at heart (J1§4) and 'better at "not being afraid"' (J1§4). Joe wonders what it is like for her to be together with him, since he too is a man. Jane ponders on this in her initial log, noting with Joe,

'there is no need to feel I have to prove anything or perform in some way, or worry about being appealing in a clever, beautiful or intelligent way. All these things are irrelevant in our relationship, as in the end, he doesn't have to like me more or think I am fantastic, as that is not the aim of our relationship.' (J1§5)

Thus, Jane reveals that she generally feels, she has to appear clever, intelligent and beautiful when she is together with men and that she makes quite an effort to get men to feel a certain way about her. In this particular setting however, she feels more free to cry without worrying, noting,

'apart from the fact that sitting and crying in front of a complete stranger feels strange, it is more relaxed than if we had a personal relationship, where I would have to worry about how he viewed me afterwards and whether I had lost prestige. And by the way, I would be very surprised if I was the only girl who has ever sat in that chair and cried, so I don’t think the phenomenon is new to Joe!!' (J1§5)

Jane views the therapy session as a special context where the rules she normally adheres to, do not apply. But as we shall see, Jane has an awareness of the challenge involved in confiding in a complete stranger, even though she does not admit this to Joe in the course of the sessions, even though he asks several times. Joe is, however, well aware of the challenge Jane faces in talking to him. Jane notes in her second log,

'I view it as an enormous challenge - laying my inner most thoughts bare to a man, and one who is a complete stranger and only being able to hope that he won’t disappoint me’ (J2§1)

Given Jane's previous experiences with men, (some of which will be presented later in the case) trusting a man must seem like a completely crazy thing to do. Jane only mentions the extent of this challenge once in her journal (J2§1). When Joe asks her what being with him is like, she makes it clear that their relationship is not personal (J1§5,Jt12§4). We can see from this that Jane uses the therapy sessions by defining them in a special way ('not a personal relationship') and by doing this she gains experience in 'being open and trusting'. This is part of her initial concern. Whether her fear is immediately lessened is not clear, but she certainly confronts it by talking to 
The Case of "J ane and J oe": A Diary-Based, Cross-Contextual Case Study

Mackrill

Pragmatic Case Studies in Psychotherapy, http://pcsp.libraries.rutgers.edu

Volume 7, Module 1, Article 11, pp. 187-229, 02-28-11 [copyright by author]

Joe. She is 'daring being open' (J1§4). Expressing this fear openly in her journal, which she knows Joe will eventually read is also an example of daring to be open. She achieves this openness by maintaining that her relationship with Joe 'is not a personal relationship'. This does not detract from the fact that Jane is in a closed room with Joe, a man, a complete stranger, with whom she is sharing her innermost thoughts. Here it is not really Joe's points of view that are the challenge. It is rather the whole therapy enterprise and setting, as a special context where you talk about your concerns and the fact that Joe is a man. The therapeutic context thus reflects certain points of view, the point of view that talking about your concerns to a complete stranger can help you, and the point of view that talking to a man can help. This is an important feature of points of view. They can be represented in contexts, such as the therapeutic context, regardless of what participants do or say.

As the therapy progresses Jane becomes increasingly clear of the points of view she has that differ from those that therapy represents. Jane notes,

'I probably have a slight tendency to keep things slightly to myself' (J5§2)

'I am quite a private person and I would prefer to be completely clear about how I feel about something or other before I talk about it to my surroundings. One of my friends formulated it quite clearly when she asked me a while ago, ' how are you really doing, Jane? With you, you first find things out, long after they 've happened!' and actually she's right. Maybe one or two friends are involved in the whole thought process, but most people first find out what I’m grappling with when the process is over. Apparently I like this best.'(J12§2)

We can see here that just as the points of view inherent in the therapy context challenge Jane's points of view, so too do friends' points of view. The points of view she is challenged by in therapy are not necessarily new and may well be, as in this example, ones she has met in other contexts earlier in her life. In this example Jane becomes more aware of her own point of view, as she ends up noting 'apparently I like this best'. Her point of view becomes clear to her during the counselling, where she begins to reflect on the connections between her emotional state and her life contexts. We will look at this feature in more detail later. However, returning to the difference in points of view, we can ask ourselves, what happens if you in the course of therapy discover that you would rather keep your points of view to yourself. A possible answer is that you terminate therapy. This is precisely what Jane decides to do after the 12 sessions.

In spite of Jane's point of view, if Jane is to get anything out of the therapy, she has to 'dare to be open' and try trusting Joe and talking to him to a certain extent. Going to therapy sessions is the diametric opposite of 'sorting things out yourself', which Jane had clearly hoped she could (J1§1). As noted, the whole idea of going into therapy reflects the point of view that talking to a complete stranger can help you. Regardless of the therapist's theoretical orientation, it is to a great extent a talking cure. Though therapists may not necessarily make this explicit, it is an implicit part of seeing a therapist. Thus, one could maintain that even seeing a therapist implies a shift in Jane's stance. In her validation of my initial draft analysis, Jane makes it clear that she was not ignorant of what psychotherapy involved, as I had suggested in my draft, but that she at the onset of therapy was 'afraid' of 'diving into the many bad childhood memories, and of how sad, this would make her'. This confirms the idea that actually starting in therapy did involve a shift in Jane's point of view. 
The Case of "J ane and J oe": A Diary-Based, Cross-Contextual Case Study

Mackrill

Pragmatic Case Studies in Psychotherapy, http://pcsp.libraries.rutgers.edu

Volume 7, Module 1, Article 11, pp. 187-229, 02-28-11 [copyright by author]

Whether this 'daring to be open' in the therapy sessions with Joe, a complete stranger, in any way affects Jane's life in other contexts can be examined in the journals. Jane mentions two possible shifts, i.e. experiences of being more open to men during the course of her sessions. Jane is open to a man she has been on a date with and tells him she is not interested in him, even though she deems him a good man. Jane finds telling him this very difficult as she experiences herself as 'cruel' and feels what she is doing is 'forbidden' (J4§1). Jane also explains later that this is different to how she has behaved with a previous boyfriend. Jane writes,

I can't remember the exact incident, but I am completely sure that it was about me not being able to bring myself to expressing how I felt in connection with something, because I might hurt him or make him sad and therefore I kept the problem to myself so he would be spared any emotional pressure! (J4§3)

This suggests a shift takes place. The second example relates to her brother, George. In her log (J12), Jane writes about sharing more feelings with him. It turns out they have similar feelings about their mother, which validates Jane's feelings. There is something about this sharing with George that is clearly new to Jane and therefore it also suggests a cross-contextual shift.

George has been visiting for a couple of days. It was really great having him here, as we don’t often have the opportunity of being just the two of us, without his girlfriend. We had a really good chat about the incident with our mother, about what it does to us, when these things happen, and how it affects us. In a way it feels reassuring, that we feel it so severely and it affects us in slightly the same way. It is also nice being able to talk about it and I feel I can be honest about my feelings and he understands what I mean. I have also found out that he reflects a lot about what he does and the feelings he has. Just like me, he is busy finding out how our upbringing affected us and how we can use this baggage constructively. (J12§1)

The shift expressed here involves a movement in two directions. Jane becomes more aware of her desire to keep things to herself and in doing this she chooses to be open in certain situations about certain things and less open about others. Where previously she seemed rather more sure that 'daring to be open was more right, and being closed was less right, Jane has discovered that she is a 'private person' and she chooses who she wants to be open with and about what. Jane chooses to be open with Joe, the professional complete stranger, by defining the relationship in a particular way ('not personal'). Jane also decides to share certain things with her brother, just as there are things she keeps to herself (her therapy at TUBA [J12§2]). By making a generalisation about what she is like, Jane creates space for exceptions and she becomes aware of certain new options.

I will now briefly return to the quotation at the beginning of this section concerning Jane's point of view concerning being private. Jane notes 'Apparently I like this best.'(J12§2). This corresponds with what Jane has written since the beginning of the first session about the fact that she would rather sort her problems out herself ( $1 \S 1)$ and that she has a tendency to keep things to herself (J5§2). The interesting thing I want to point out here is the use of the word 'apparently'. During the course of sessions with Joe and in her ongoing private life, Jane becomes aware of her points of view in a new way. This is a feature of many shifts in this case. I will explore this feature in greater depth at a later stage. 


\section{NOT BEING AFRAID}

I have noted in the last section how one of Jane's initial goals in relation to 'finding a man' is to get better at 'not to being afraid' (J1§4). As Jane describes her life, it becomes clear that it is hardly surprising that Jane gets frightened in the presence of men. The data show us, that contrary to her belief, Jane is either extremely good at 'not being afraid' or exceedingly good at concealing her fear. She mentions her fear of being together with Joe once (J2§1)) and she manages to spend twelve sessions with Joe, a man, a complete stranger. As we can see from the previous section, Jane somehow seems to make her fear of being with Joe disappear to a great extent by defining the relationship as 'not personal' (J1§5). This seems to offer her some form of magical protection. I say magical as Jane experienced trusting a social worker [pædagog] previously. He worked with her family for several years when she was in her teens. When she was 19 and visiting him (and he was 46), he told her he had fallen in love with, thereby expressed sexual interest in her. This overstepped her boundaries, as she viewed the relationship as one of paternal support (J10§1). Given this example and many others from her childhood, the striking thing in Jane's diary is the general absence of writing about fear in the presence of Joe. This brings me to the conclusion that Jane is either exceedingly good at 'not being afraid', or she conceals her fear. As we shall see in a later section on the 'dual perspective', Jane does begin to find a way to live with her fear. A shift begins to take place, a shift from wanting not to be afraid, to learning how to be afraid. I will look into this issue later.

\section{USING FRIENDS AND RELATIONS}

As I have mentioned, Jane's primary focus in her diary is the analysis of her life. She does this with Joe, but she also examines her life in other contexts. An example of this is when Jane (J1a§5-7) visits a friend after her first session. The friend is also a client at TUBA, and the friend was instrumental in referring Jane to TUBA. Jane has spoken to her previously several times and has had 'good chats' after they found out they both had grown up in families with alcohol problems. Jane mentions her first session with Joe to her friend, noting,

\footnotetext{
"This led to a really good chat about the many problems you run into, when you are the child of an alcoholic. We talked for over three hours, so we covered a lot of ground, but it just felt really nice to be able to talk off the cuff and know that she understood how I felt and exactly what I was talking about. (...) One thing we talked about was boyfriends, the good ones, the bad ones and the non-existent ones. It seems we can both have problems maintaining and sanctioning our personal boundaries with boyfriends...(...) As far as my position is concerned, I think it's about me being so eager to sense "where he is" all the time, how he is doing and how he thinks and feels, that there simply isn't room or energy to sense where I stand and how I feel about being right there, and this results in my not noticing when he has overstepped my boundaries, before it is too late and the damage is done' (J1a§6-7)
}

"It seems I have some sort of idea that at some level or other it is my job to make sure he is happy. (Happy in this connection, I think I connect with peace and quiet and the absence of physical and emotional conflicts)" (J1a§9)

Jane uses a friend in another context to investigate and reflect her understanding of her own situation. She notes both similarities, 'we both have problems...' and she also tries to develop and understand aspects of her situation that are not necessarily similar to her friend 'as far as my position is concerned...' She is busy developing her points of view in this meeting with a friend. We can see this in the tentative way she writes about her own points of view, noting 'I think it's 
The Case of "Jane and Joe": A Diary-Based, Cross-Contextual Case Study

Mackrill

Pragmatic Case Studies in Psychotherapy, http://pcsp.libraries.rutgers.edu

Volume 7, Module 1, Article 11, pp. 187-229, 02-28-11 [copyright by author]

about me...' ' I think I connect with...', 'it seems...'. Previously, I presented an example of Jane saying 'apparently...' We can see how Jane uses intersubjective meetings with Joe and others while she is in therapy in the consideration and assessment of her own points of view. She compares her experiences and points of view with her friend. She tries points of view out and tentatively explores them. I have in the course of this section introduced the term 'tentative point of view'. Previously I have used the term 'adopted' point of view. Jane tries points of view out like new pairs of glasses to see if makes the world seem less opaque. Then she may adopt the point of view in certain situations, whereby the point of view becomes a possibility.

Jane uses talking to her friend as a foil to explore her own points of view and as a method of validating her points of view. This is also the case in a previously mentioned example where Jane notes relief that her brother George has similar feelings to her, in relation to their mother. We have also previously seen how Jane recalls a talk with a friend in the past to validate the point of view that she is a 'private person' (J12§12). So too in this log, Jane finds 'talking of the cuff' and 'knowing she is understood' 'nice' (J1aß6). Jane expresses opinions to her friend and hears her friend's stances and develops her understanding of her own situation in these meetings. In this example, Jane is engaged in an investigation with a friend of how she behaves in couple relations. Jane is investigating how growing up with a substance abuser affects her relationships with boyfriends. The shift in emphasis from being wrong in relation to boyfriends and needing putting right, to investigating what is and why it is, clearly takes place across contexts. I have noted this shift earlier, but as this analysis progresses, I hope our understanding will increase.

The tentative point of view that Jane explores in these quotations is that in couple relationships, she focuses on maintaining a particular emotional state, 'happy', in the other, to avoid 'physical and emotional conflicts' and thus maintain 'peace and quiet’ (J1a§9). This point of view involves an absence of focus on where she stands and how she feels. Jane expresses an other-focus and a lack of I-focus. She focuses on herself as an instrument in the service of others.

When I refer to Jane's I-focus. I am referring to two aspects - her monitoring of her subjective emotional state in connection with the situations she is in and her assessments as to whether she would rather move elsewhere. I focus - is an assessment of her orientation as a whole. It is an assessment of her engagements/commitments as a whole. I-focus is not just one concern among others. It is the basis of being concerned.

In the previous quotation Jane described what I call the I-focus with the following words, 'where I stand and how I feel about being right there' (J1a§7). Jane is aware of her presence, but she often experiences her presence from a third person perspective, as an instrument in the maintenance of 'happiness' in the other, or as an instrument in the maintenance of peace and quiet in her environment.

In this example, we can see how Jane uses her friend in the development of her point of view concerning finding a man. We can also see how Jane's concern regarding 'finding a man' has shifted. Jane's investigations of her point of view have led her to a new focus in her man-finding project. She is in the process of discovering that her man-finding problem may be connected with a lack of I-focus. Thus developing an I-focus becomes a new concern running parallel to and 
The Case of "Jane and Joe": A Diary-Based, Cross-Contextual Case Study

Mackrill

Pragmatic Case Studies in Psychotherapy, http://pcsp.libraries.rutgers.edu

Volume 7, Module 1, Article 11, pp. 187-229, 02-28-11 [copyright by author]

connected with her search for a man. One could say that the shift involves Jane, in pursuit of one concern (finding a good man), picking up and trying a new and connected concern, the I-focus, on her way. A feature of the development of points of view seems to be how one investigation 'sparks off' others. One investigation 'picks up' others on its way. We can examine this feature in more detail later. Let us now follow the new concern that has been picked up.

\section{THE SEARCH FOR AN I-FOCUS.}

In the last section I have shown how Jane pursues and develops her concern outside the therapy room. But it would not be a fair representation if I did not examine whether the interaction in the session might have played a part in this shift. The quotations in the previous section are from Jane's second log after the first session (J1a). Let us now consider the first session and look at Joe's log after the first session to see what he deemed significant and see if he introduced the idea of I-focus. Prior to this, it seems important to mention that, focusing on one's own emotional state and the situations one is in is an implicit part of being in therapy. It is difficult to talk about yourself and your life to another person for an hour without becoming more aware of how your life is and what it feels like being you, almost regardless of what the therapist says or does. Once again the therapeutic context reflects a point of view beyond explicit therapist intentions, the point of view that how you are doing, is significant.

However Joe also presents the point of view that I-focus is important. Joe emphasises I-focus in a variety of ways. One way he does this is by weighting his own emotional state when together with Jane. By doing this he presents the point of view that this is a possible and legitimate thing to do. This is a very different point of view to one that just emphasises the other's being 'happy', as Jane initially does (J1a§9). Joe also does this using the word 'contact'. Already in the first paragraph of his log he writes,

'An important thing today was that our contact was good.' (Jt1§1)

Good contact seems to involve both monitoring his own and Jane's emotional state when they are together. Emphasis on 'contact' thus involves I- and Other focus. Other focus in this situation has to do with Joe's attention to how Jane is doing and I-focus has to do with how he is doing with her.

Joe emphasises the significance of Jane's experiences. He focuses both on what she feels needs doing, but he puts a different slant on what she says, by focusing on,

'the experience of being sad in various situations when she is alone with herself; when she happens to think about old situations in her childhood......' (Jt1§2)

This is a different perspective to Jane's. He is engaged in examining and imagining what it is like being her, which is very different from her point of view concerning how she ought to be to make others 'happy'. Joe goes on to write,

' Generally I imagine that Jane is often quite lonely, even though she has many social contacts. There is something about her preferably managing by herself and I sense also a slightly hard "that's just the way it 
The Case of "Jane and Joe": A Diary-Based, Cross-Contextual Case Study

Mackrill

Pragmatic Case Studies in Psychotherapy, http://pcsp.libraries.rutgers.edu

Volume 7, Module 1, Article 11, pp. 187-229, 02-28-11 [copyright by author]

is" attitude to herself regarding this. She is not allowed to whinge and perhaps not really need others. It is vulnerable.

There is something about her holding a lot of (inner) life back in her relations with others. Perhaps this means she has a feeling of not using/giving herself completely and perhaps not living up to her potential, which she senses she has.' (Jt1§6-7)

We can clearly see here how Joe is in engaged in a vicarious I-focus, in other words other focus. He focuses on what he imagines being Jane is like. As previously shown, Jane is far less focused on her sense of being, and in a sense he is focusing on this for her. She is more focused on others' sense of being and keeping the peace. Thus there is a massive difference in point of view. Joe is very engaged in Jane's perspective on life, where she is initially generally engaged in others' perspectives. This difference becomes even clearer later in Joe's log

'We started on what seemed most pressing, the grief and sadness concerning past incidents. She told me about the situation when she was ten and was sent with a man she didn't know to buy drugs and then he abandoned her. She felt the grief to do with being let down by her mother and the fear in the situation.' (Jt1§8)

Later Joe writes about the same incident,

'I think it is very significant in the long run that she does not bear this alone, but shares how it was and how she senses it now with someone.' (Jt1§7)

Joe is focusing on Jane's experiencing the past in the present in the presence of another human being, him. Once again this goes to show the difference in point of view. He focuses on sharing and on her experiencing. Jane does not mention talking about this incident in her logs (J1, J1a) suggesting she does not find it particularly significant. Jane is caught between wanting to accept and forget, and she tends to focus on others' experiences, and her own becoming different. Joe points out, that they can talk about how they are getting along together, which moves Jane. Jane notes,

'Apparently I don't expect there to be room for my needs and that they will be met. Apparently I don't count on there being any focus on how I am doing...' [The Danish word for I, “JEG”, is written in capitals for emphasis. Generally "jeg” is written with small letters. tm.] (J2§1)

We have now moved on to the second session and we can see here once again how Jane becomes aware of her own points of view concerning her lack of I-focus. Note the use of the word 'apparently' twice. Jane's journal, written in the first person, gives us the experience of following Jane as she becomes aware of a whole series of points of view, the lack of an I-focus being one of them. The above quotation also shows how Joe expresses the point of view that Jane's subjective stance is significant, not just to her, but also to their being together. This focus would also be important in relationships with others, including possible future relationships with 'good men'.

\section{TRYING NEW POINTS OF VIEW OUT}

We have already seen how Jane after the first session tentatively begins to pick up on Joe's points of view and begins to investigate connections in her life with a renewed sense of 
The Case of "Jane and Joe": A Diary-Based, Cross-Contextual Case Study

Mackrill

Pragmatic Case Studies in Psychotherapy, http://pcsp.libraries.rutgers.edu

Volume 7, Module 1, Article 11, pp. 187-229, 02-28-11 [copyright by author]

conviction. I am not suggesting that Joe in some way plants new points of view in Jane. I am sure Jane has spent time both investigating her life and focusing on her subjective emotional state prior to being in therapy. I am suggesting that by Joe's practising these points of view, he gives Jane the opportunity of experiencing these points of view in action. By doing this he supports Jane in similar actions. Jane may have and probably has met people with Joe's point of view previously (see for example J4§3 where Jane comments how Joe says the same as a friend has said). One can ask, what is the difference between talking to a therapist and talking to friends. Perhaps with time I will offer an answer to this question. Until then, I will only note that in the therapeutic context, a context that focuses on personal development, Jane comes across points of view and, as we can see, she adopts some of them tentatively and begins to investigate them in the therapy session and in other contexts with increased resolve. Jane also reconsiders points of view she has come across earlier in her life and she compares these points of view with Joe's points of view. In her logs, we also find Jane experimenting with maintaining her focus on her subjective emotional state in a context outside the sessions. Practising this point of view becomes a new concern for Jane. Let us now look at this example concerning a man Jane has been on a date with,

'I can sense that the date I was on with that man has occupied me to great extent. I've thought a lot about it and have constantly tried to sense and feel and sense a little more how I have felt on my way and what things it arouses in me.' (J4§1)

In this example, we can see how Jane is trying out focusing on her own subjective emotional state in a context outside the therapeutic session. This is another example of a cross-textual shift. Previously she focused on making others 'happy' and her being wrong. In the example she is focusing on what it is like being her.

As I have noted, Jane is instructed to write about new and different experiences in her journals. In connection with her date Jane also notes another difference in experience.

'I am trying to reflect on things as I go along without hurrying myself or forcing anything. Here I am particularly thinking about the man I've met, where I can feel [mærke], that it's important to me that it doesn't go too fast, so I feel I'm being pushed into things [at der bliver presset ting over hovedet på mig] and I end up slamming on the brakes’ (J3§1).

This is clearly a part of what I call focusing on her subjective emotional state or the I-focus. However it also involves another aspect of this shift. Previously Jane has noted how she with boyfriends 'is ahead' [på forkant](J2§1), is 'ready to take care of him’ (J2§1), feels she needs to be 'damn cool' [pisse tjekket] (J2§1) and as Joe notes,

'she is the one who controls everything, is ahead, is in the other, smoothes things out, prevents conflicts' (Jt2§3)

What we can see here is Jane experimenting with a shift in point of view from being ahead and trying to control events in a variety of ways (taking care, being cool etc.) to being in the process and trying to following what happens. To use Jane's words, she seems to be 'practising being relaxed in the company of the opposite sex' (J3§1). Jane describes how the slow pace of things is necessary if she is to maintain her focus on her emotional state. Thus, it is part of Jane's developing an I-focus. We can see how she practises this focus outside the therapy session. 
The Case of "Jane and Joe": A Diary-Based, Cross-Contextual Case Study

Mackrill

Pragmatic Case Studies in Psychotherapy, http://pcsp.libraries.rutgers.edu

Volume 7, Module 1, Article 11, pp. 187-229, 02-28-11 [copyright by author]

\section{CRUEL IS SOMETIMES RIGHT}

In telling her date, that she was not interested in him, Jane felt she should be ashamed of herself [det kan jeg simpelthen ikke være bekendt](J4§1). She felt she was 'cruel' [ond] (J4§1) and she felt it was 'forbidden' (J4§1). Joe supports Jane in talking to her date and in maintaining her point of view that she is not interested in him even though she feels 'cruel' by telling him so $(\mathrm{Jt} 4 \S 2,6)$.

Joe continuously draws attention to how Jane experiences her life. At the same time he supports Jane in doing something that she feels is 'cruel'. This must challenge Jane significantly. At one level Jane considers what she is doing as wrong and at another level, she finds it justifiable and right. Jane experiences ambivalence as she increasingly focuses on her own experiences and she is confronted with conflicts with others.

The framing of experience in right and wrong seems to be a general theme in Jane's journal. Let us look at another example of this. Joe presents the point of view that being in touch with your feelings is a gift and Jane writes in response to this,

'honestly, its doesn't feel like that' (J3§3)

What we can see here is that points of view presented by others, in this case Joe, seem wrong, i.e. Jane's immediate response is to dismiss his point of view. However in the context of being in therapy, Jane reflects on both her own position and Joe's noting,

'returning to Joe’s point of view, I haven't thought of things in that way before, that at one level sensitivity is a gift. I will just have to consider this a little. (J3§4)

Thus in therapy, Jane reflects on her points of view in the light of others' points of view in some form of resolute way. Resolute here refers to the way Jane's keeps hold of Joe's point of view as a foil against which she reflects and develops her own point of view, even though her immediate sense is to dismiss it. She employs an other-focus in the development of her I-focus. Thus, if I am to define a shift here, it has to do with instead of defining experiences as right or wrong, beginning to define them in relation to differences in perspective, which involves the maintenance of an own perspective, an I-focus.

Joe presents a point of view in the situation where Jane finds out she doesn't have feelings for the man she has been on the date with, and when she feels she is 'cruel'. According to Jane,

'It was actually also slightly strange to hear Joe say something like that I was not responsible for John's [the date tm] feelings. It brought me back to my old relationship, where I can remember my girlfriend at some point in time said exactly the same words.' (J4§3),

The point of view Joe presents here isn't new to Jane. He is saying the same as a friend said. Thus, as I have noted, what is said in therapy is not necessarily new or special. What is new is that Jane is in therapy, understood as the fact that she is in a process of personal development. She gives Joe significance in this process, just as she makes what friends have said in the past 
The Case of "Jane and Joe": A Diary-Based, Cross-Contextual Case Study

Mackrill

Pragmatic Case Studies in Psychotherapy, http://pcsp.libraries.rutgers.edu

Volume 7, Module 1, Article 11, pp. 187-229, 02-28-11 [copyright by author]

significant in a new way. They both tell her what she considers wrong in this situation is the right thing to do. In meeting Joe's point of view, Jane becomes aware of her own stance and prepares the way for a shift.

'Apparently it's a pervasive theme for me, that I for God's sake must not trouble people or make them sad by laying my emotional troubles on them' (J4§4)

Jane continues in her log noting, that

' ... as a general rule, one should avoid making people sad, but perhaps it's just not always possible [men det kan man måske bare ikke altid]'. (J4§4)

Thus another of Jane's points of view is challenged. She has once again become aware of her own point of view. This time the old boyfriend (who she spared telling how she felt (J4§3)) the girlfriend (who told her she was not responsible for the former boyfriends feelings (J4§3) John, the date (who she tells how she feels) and Joe the therapist (who also tells her she isn't responsible for John's feelings) are all involved in Jane's shift. Once again Jane tentatively speculates on Joe and her girlfriend's point of view, noting 'perhaps' making people sad is unavoidable sometimes. Jane does manage to tell John, the date, that she doesn't have feelings for him and thereby she does risk making him sad. She does something she feels is wrong; something her girlfriend and Joe say is right, and it works out for her. This is another example of a shift.

\section{RECEIVING CARE}

As I have noted earlier, as a phenomenon, psychotherapy is anything but linear, which makes writing about it a challenge. Therefore we will now rewind and follow another theme.

'and it suddenly occurred to me that I am not particularly good at receiving care’ (J2§1)

Joe presents another point of view that is new to Jane. Jane notes in her diary that Joe,

'said, if I at some point felt uncomfortable in relation to the fact that he is man, raising the matter and talking about it was quite ok'. (J2§1)

This is another example of an intersubjective meeting. Jane is moved by what Joe says. As she notes, it is a point of view, she is not used to hearing.

'Apparently, I don't expect there to be room for my needs and that these will be taken care of. Apparently, I don't count on there being focus on how I am doing.' (J2§1)

This is a clear example of the difference in point of view concerning I-focus that has been discussed. Jane becomes aware of her point of view through an intersubjective meeting with Joe. As mentioned Joe makes it clear that they can talk about how they are getting along and take each other's views into consideration in the process. What Jane also experiences here is Joe showing consideration for her and this makes Jane aware of the fact that receiving care is difficult for her. 
The Case of "Jane and Joe": A Diary-Based, Cross-Contextual Case Study

Mackrill

Pragmatic Case Studies in Psychotherapy, http://pcsp.libraries.rutgers.edu

Volume 7, Module 1, Article 11, pp. 187-229, 02-28-11 [copyright by author]

The difference in points of view challenges Jane in other ways. We have seen how Jane has become aware of the fact that she does not expect her needs to be met, or attention to be paid to how she is doing. Put the differences in point of view also spark other awarenesses in Jane. She discovers she has difficulty receiving other people's care and attention. Jane then investigates what she does when she is in the vicinity of potential care-givers in her journal. First, she does this considering relationships to boyfriends,

'I quickly become mother-like and take responsibility for how the boyfriend is doing (just as I did with my mother, as child)' (J2§1)

Jane looks for connections with past contexts, a subject that I will investigate in more detail in the following section. In her journal, we can see how Jane uses the experience with Joe as a foil against which she considers her relationships with boyfriends. Jane's experience with Joe leaves her in quite a spot. She finds she does not know how to receive care. Jane notes,

'I am used to being the one who gives and sacrifices herself, and if everything is suddenly turned upside down, then I really don’t know what to think at all' (J2§1)

On discovering this, Jane quickly attempts to fill the void. She imagines a new way of being together with boyfriends in future contexts, i.e., a potential new point of view. We can follow Jane's thoughts in the following three quotations that follow chronologically in her journal.

'If I, as a mental experiment, imagine being in a relationship, where I am not to be the one who gives, 'takes care of' and sorts things out, then I envisage myself as a passive, rather boring person who is a bit of a liability to be with' $(\mathrm{J} 2 \S 1)$

'In a "perfect” relationship, I suppose there is an exchange between giving and receiving intimacy and care, so maybe for me it's a matter of finding a balance and not least telling myself, that receiving is actually ok, and that you don’t have to be so damn cool [tjekket] all the time.' (J2§1)

'....it gets out of control, I deny boyfriends the possibility of 'taking care of me', as I am always ahead and am ready to take care of them.' (J2§1)

Here we can see how Jane uses the stance Joe has taken in showing her consideration. Jane investigates her relations to boyfriends in other contexts. First she investigates her point of view in relation to past contexts. Then she becomes aware of a missing point of view for the future. Then she mentally tries out one potential point of view (letting the other person give and remaining passive herself). She finds this potential position unsatisfactory. Then she tries a new potential future point of view out (the idea of an exchange in care taking) which she seems to prefer. Jane also proposes ways of supporting herself in future contexts (by telling herself she doesn't have to be so cool), so she can try 'receiving care' out. We can see here how the void is quickly filled. She tries points of views out in imagined contexts.

In an interesting twist at the end of this log, Jane also makes the valid point that her receiving care is also a matter of giving, ('giving him the opportunity of taking care of me' (J2§1)). Receiving care can thus play a part in making the other 'happy'. Making other people happy and not focusing on her subjective emotional state is something that Jane has previously noted as 
The Case of "J ane and J oe": A Diary-Based, Cross-Contextual Case Study

Mackrill

Pragmatic Case Studies in Psychotherapy, http://pcsp.libraries.rutgers.edu

Volume 7, Module 1, Article 11, pp. 187-229, 02-28-11 [copyright by author]

typical for her. Now she has found a stance that involves keeping both her and a potential boyfriend 'happy', employing an I-focus. Thus we can see how Jane uses the journal and other people to grasp her life across time and space. She connects the present context (with Joe) to other contemporary contexts (with boyfriends), looking at connections with past contexts (with mother and former boyfriends), and imagines future contexts and potential points of view. These analyses are not just made by Jane in her journal; some of them are also made in the session (see Jt2§3).

Shortly after this, Jane is on a date, and here Jane experiments with new points of view concerning receiving care,

'on this date I was very conscious of standing back and giving him space to take the lead e.g. I let him take care buying tickets, ordering sandwiches... When there were breaks in the conversation I was very conscious of not asking about him right away, which is usually what I do, almost instinctively. I tried to tell myself, that the (“embarrassing”) break didn’t mean anything and that I was completely relaxed about it (even though I was completely conscious of the fact that neither of us was saying anything). And then I noticed, that after a while he actually asked about me, or my work, or something else, which was a great experience. So it also went according to plan’ (J2a§2-3)

Jane now practices a new point of view in another context. She has moved from using the point of view in an imagined context to using it in a real context. The potential point of view is now employed tentatively. Jane is experimenting and concludes that the experiment is a success. When she stands back, she experiences her date's interest in her. However standing back seems

'rather silly and unnatural, letting others 'care for me', so perhaps I can learn to relax about it'(J2aß5)

Once again we are back to an example of Jane learning something that does not feel 'right'.

Jane develops her understanding of her man-finding concern further, this time noting,

'The challenge for me probably lies in trusting that other people also have abilities and, besides this, giving them the space to show them. Maybe, I don’t have to do everything myself?' (J2a§5)

Once again a new concern is picked up. Let us now follow the route Jane has followed. First there is the intersubjective meeting with Joe. Joe presents the different point of view, that talking about how we are getting along, and taking each other's views into consideration in the process is a possibility. Jane is moved by this. She becomes more aware of her point of view, that she has difficulty in receiving care. The possibility of care for her is considered. Jane develops her own point of view by trying out potential points of view (from the idea of merely receiving care to the idea of an exchange of care). Jane then experiments with a point of view tentatively and in doing this she develops a new concern. The new concern has to do with learning to allow another person to care for her. She does this by standing back and giving people space to show abilities, i.e. experimenting with receiving care. This leads her to a potential new point of view, the point of view that she may not have to do everything herself (J2a§5). A series of shifts is taking place, across real and imagined contexts, across real and potential space.

In the course of therapy, new points of view are picked up and experimented with. New concerns are developed and pursued across real and imagined contexts and in the pursuit of these concerns 
The Case of "Jane and Joe": A Diary-Based, Cross-Contextual Case Study

Mackrill

Pragmatic Case Studies in Psychotherapy, http://pcsp.libraries.rutgers.edu

Volume 7, Module 1, Article 11, pp. 187-229, 02-28-11 [copyright by author]

new points of view develop. In this example we must remember that these concerns and points of view have been 'picked up' in the pursuit of several concerns including 'finding a good man'.

The point here is that in the pursuit of one concern any number of points of view may be challenged and this seems to be beyond the control of the client and therapist. It is rather like being on a beach and pulling the end of a rope that is sticking out of the sand. You have no idea when you pull the rope how long it is or what you will discover hanging on to it, or whether you will be able to pull it up or indeed how much of it you will be able to pull up. Jane notes in log $\mathrm{J} 2$ when she is in the process of investigating what she is like in relationships with men,

‘Suddenly I am also becoming unsure about what I bring into relationships’ (J2§1)

We can see how new points of view or voids in points of view become apparent to Jane. Jane continues this investigation into receiving care in later logs, for example, noting

'when you lay your sadness on another human being(...), then there is a chance that the person cannot contain your feelings and you risk being disappointed. So maybe it has to do with the fact that I can more easily grasp being sad, if I don't have to be simultaneously disappointed when the person I trusted to take care of me and my feelings, proved not to be capable of it.' (J4§6)

Jane continues to develop her point of view about receiving care. She is developing her point of view concerning the risk involved in receiving care. This is interesting as Jane here also challenges one of her earlier points of view concerning 'not being afraid'. In the pursuit her manfinding concern, risk has surfaced as a theme. It appeared earlier briefly in relation to Joe (J2§1). The point of view concerning living with risk differs from one concerning 'not being afraid'. Exposing yourself to care involves exposing yourself to risk and this involves the fear of disappointment. Once again this show how points of view are in no way isolated. They are interrelated. Challenging one point of view leads to confrontation with others in unforeseen ways. As we can see, many of the points of view in Jane's therapy are connected with what it takes to get an intimate relationship to work. Let us leave this theme here, as it will reappear later.

\section{THE REAR VIEW MIRROR}

'Now I can see (I must admit, only in the famous rear-view mirror, but anyway) that it gets out of control ...(J2§1)

In this section I will look at how Jane begins to use the past to understand the present. This is a point of view that Joe presents on several occasions. Once again we will rewind and follow this point of view.

Jane becomes clear of the fact that 'forgiving and forgetting' doesn't work for her as the past continues to intrude into her consciousness and she has to find another strategy (J1a§4), noting 'perhaps part of me won’t let me forget' (J1a§3). Joe offers a point of view, concerning investigating the past. Again and again, Jane is encouraged to look for connections between her present emotional states and her past. For example, already in the first session as I have mentioned, Jane examines how she is more aware of how her former boyfriends would feel than how she felt (J1a§7). In the therapy, they delve into the past to understand this, Jane notes, 
'I talked to Joe a bit about how as a child I was constantly subordinate to my mother's feelings and needs and she took up an enormous amount of emotional space. In connection with this my job was to "make the atmosphere good", by as far as possible, removing disturbing elements, so my mother's needs could be met. This could involve cleaning the apartment, making sure George [brother. tm] wasn't noisy, keeping out of the way or making sure conflicts didn't arise. The fewer things mother had to speculate about, the lower the stress level in our lives. In other words: when mum was happy, we were all happy.

I think I can see I transfer some of the same elements in my relationships with boyfriends. If my boyfriend is happy, I am happy’(J1aß8-9)

Joe continually pursues his search for connections between the present and the past. Let us look at another example. In this next example Jane is writing about how 'cruel' she feels and how forbidden it feels to tell her date that she isn't interested in him. Jane notes,

'Joe suggested this might be connected to my mother and the relationship we had as a child. In the way my feelings were ignored and disparaged, if they were expressed at all, for the sake of my mother's feelings and needs.' (J4§1) 'If this is still the model that I employ, perhaps it's not surprising that it feels strange and not least slightly dangerous imposing my feelings on others, which I feel I do when I have to tell John [the date] that I don't have the same feelings for him, that I sense he has for me. (J4§2)

The therapist offers Jane a way of understanding the feeling that she is doing something wrong. In the context of her childhood it makes sense. Otherwise as she notes, 'it feels forbidden and I feel bad about it.' She feels she is being cruel and notes that since the previous night when she decided to tell him she wasn't interested in him, she has had a stomach ache 'out of sheer nervousness as I will rebuff his feelings' (J4§1). Jane uses the past perspective as Joe suggests to calm her down, even though she has, as yet, not fully accepted Joe's point of view. Her point of view is still tentative, as she notes 'if' the model she is employing is the one from her childhood, then 'perhaps' her situation is understandable (J4§2).

Joe shows Jane how to look into the past and how to use the past to understand the present. This is clearly one of the things Jane values most highly in her therapy. In her final log Jane notes,

'The greatest experiences I have felt during the course of treatment have actually been when I could see a connection between the influence of my childhood and my behavioural patterns as an adult. This gives me a sense of there being meaning in the madness and that everything has a natural cause. This alone can give me a feeling of calm and satisfaction, that I now have more insight into another part of me, however small it may be.' (J12a§1)

But the skill of looking into the past that Jane learns is far more complex than this presentation suggests. Looking into the past is not new to Jane. She is used to it and often experiences intrusive memories. Jane makes this clear noting,

'My 'problem' is that I have thought about and analysed these experiences many times on my own and it doesn't really help me get less sad. Joe pointed out in connection with this that I have always been alone in these situations; just as I stood alone when I experienced them, and telling them to him, that is another person, could make a difference.' (J1aß2)

Jane faces several dilemmas here. Looking into the past provides relief. It gives a sense of 'meaning in the madness' (J5§2, J12a§1). However, it has a price. Finding meaning involves confronting sadness, which Jane wants to avoid, as she feels she is too sad. We can see here how Joe's points of view are interrelated. If Jane is to accept the relief looking into the past can offer her in understanding the present, she faces the daunting task of confronting the past and the 
The Case of "Jane and Joe": A Diary-Based, Cross-Contextual Case Study

Mackrill

Pragmatic Case Studies in Psychotherapy, http://pcsp.libraries.rutgers.edu

Volume 7, Module 1, Article 11, pp. 187-229, 02-28-11 [copyright by author]

sadness involved in this. Joe also has a point of view, concerning dealing with the past. It involves sharing. But this also challenges Jane's point of view, as she likes to keep things to herself (J5§2, J12§2). Let us look at these issues in turn. Picking up one of Joe’s points of view (understanding the present by looking at the past) challenges Jane in a series of ways. It challenges Jane's wanting to forget, her not wanting to cry and her wanting to keep things to herself.

In spite of all this, Jane notes that seeing the connections between the influence of her childhood and her behavioural patterns were the greatest experiences in her sessions (J12a§1). We have already seen many examples of how Jane uses the past perspective to understand her present situation.

\section{TOO SAD}

Early on in the course of therapy, Jane starts investigating her sadness rather than just trying to rid herself of it. Jane is in a dilemma. She continues to want to rid herself of it, but she also investigates it. In connection with this, Joe presents a point of view, which is very different to Jane’s. For Joe, 'being in contact with one’s feelings is a gift' (J3§3). In contrast to this Jane note’s, 'being at the mercy of my feelings [i mine følelsers vold] is a strain [belastende]' (J3§3). Joe also presents other points of view concerning crying. Joe refers to,

'an important talk about her relationship with her brother, where she feels much tenderness and love and is extremely moved [berøres meget] when she puts it into words [sætter ord på] - [this is] something she knows from many situations, where she experiences feelings of love between people. She is not used to sharing these feelings and also because she is amazed by the strength of the feelings and because she connects crying with being sad which isn't the case here. It is being touched [berørthed]. I share my thoughts, that it may be to do with an important need to express oneself, that she has, and that the strength of her feelings might not diminish before she starts getting used to expressing them in words.' (Jt3§4)

'When Jane talks about love, she is touched in her heart and the tears are different from when she is sad about being let down in the past...' (Jt3§11)

Joe differentiates here between being sad about being let down in the past and being touched by feelings of tenderness and love. He is framing being 'touched in the heart' as something positive. Joe seems to be hinting at the fact that wanting an intimate relationship generally involves letting oneself be touched by feelings of tenderness and love. As we will see later in this section, Joe defines the other sadness as grief. We will look at this more closely later. What Joe presents here is the point of view that there are different types of sadness that should be understood and dealt with differently. Joe presents this point of view, as he is not sure Jane is aware of this difference.

Joe also presents a point of view that crying also has to do with expressing oneself. For Joe, the way to get less sad involves sharing, which involves putting into words and having someone to express oneself to.

Jane investigates why she finds crying so problematic. Jane looks into her past and notes, 
The Case of "Jane and Joe": A Diary-Based, Cross-Contextual Case Study

Mackrill

Pragmatic Case Studies in Psychotherapy, http://pcsp.libraries.rutgers.edu

Volume 7, Module 1, Article 11, pp. 187-229, 02-28-11 [copyright by author]

'It's not that I think there is anything wrong with crying. It is just that I've experienced that, as I've already said, my reactions have been relatively out of proportion [uforholdsmæssige], and I think this limits me in my expression. I have experienced that I haven't said no [fået sagt fra] to my mum, because I sense I would start crying...then she comforts me... and once again I'm the (hysterical) little girl, whose words and feelings have no power. Is this perhaps really to do with my being misunderstood when I cry? That I loose influence, credibility and authority when I cry in front of others? It actually might be... (J3§3)

Jane's initial point of view is that 'crying too much' is 'wrong'. On investigating, Jane discovers that perhaps it is not the crying too much that is 'wrong', but the loss of influence, credibility and authority. This point of view is very different. It is the reception or response to the crying which is wrong, not the crying. Jane uses her own words, but the point she makes is similar to Joe's point of view that sadness is also a form of expression implying that its reception is an important aspect of dealing with it. Jane’s mother did not appreciate what Jane was trying to express.

Jane develops this point of view later in her $\log$ (J11), when she writes about a situation where her mother has taken some form of drug again. Jane notes,

'I think she belittles my feelings, when I sense (mærker) she thinks I am overreacting, when I, for example, get sad because she drinks.' (J11§5)

Jane has developed her point of view and seems surer of her assessment that it is her mother's reception of her feelings that is problematic, rather than her crying too much that is problematic. Jane expresses a clear point of view here about not accepting having ones feelings disregarded. This suggests a shift. The point of view is still expressed tentatively, as Jane writes that she 'thinks' her mother belittles her feelings.

The feeling of there being something 'wrong' is made sense of in a new way. There is a shift from 'me being wrong' to 'it being wrong' (the loss of influence, credibility and authority connected with mother's behaviour), or 'the reception of what I was expressing was wrong'. It is a shift from 'I am wrong' to 'it is wrong', from internalisation to externalisation of the sense of 'wrongness'.

Prior to this shift, Jane has steadily become more confronted with her sadness as its connections with her life contexts are explored. In the sixth session, after sessions dominated by topics such as the date, the fear of family members dying, and the investigation of why Jane feels better, the subject, being too sad, returns. Jane notes,

'I am still frustrated, as I can’t talk about my childhood without being emotionally touched (read: cry)’ (J6§1)

Jane has again spoken to her Joe about this and comments that she is beginning to give up on her point of view concerning 'forgetting', as we can see,

'I see there are things that I obviously have not dealt with or accepted or whatever it is I must do with these sad childhood memories or when pictures of memories which make me sad turn up on my retina. As a rule they are of situations that weren't nice for me to be in or where I was frightened, sad or tense. The pictures turn up in my inner eye completely spontaneously. Sometimes several times a day, other times only when I am trying to sleep and can't fall asleep and on other days there are none.'(J6§1) 
Jane has as yet not found a new point of view that can help her deal with these sad memories, nor has she fully given up on her point of view concerning forgetting. Whereas going on the date was the central issue in the previous session, now the past has again become present for Jane in a new way as the intrusive memories from the past take centre stage in Jane's therapy and her consciousness. Jane considers how she can deal with them, not just in the therapy sessions but also in her everyday life. She considers how she can use the therapy. Jane follows the point of view involving investigating what is, rather than trying to rid herself that which is. So when the intrusive memories appear, Jane gets sad and investigates, rather than immediately trying to rid herself of the problem. Jane notes

'As a rule, it's not the good stuff I remember either. On the contrary, it's the bad stuff that turns up and makes me sad, when I need it least of all. In connection with this, we talked about what I actually do when they turn up, whether I deal with the, and if so how. I've said I will spend some time paying attention to this. My immediate impression is that all I do is get sad, maybe cry, agree with myself that it's damn unfair that my childhood was so turbulent and I am tired of the fact that it slightly hangs over me like a shadow. After this I try and shake the feeling off and think of something else. In connection with this loads of thoughts, relevant and irrelevant from yesterday, today and tomorrow circulate in my head, so changing my train of thought [skifte tankebane] usually happens all by itself after a while.' (J6§2)

Following on from this, Jane considers writing her thoughts down.

'Maybe it would be an idea to write the 'pictures' down, that is describe the individual occurrences and the feelings I have at the time. Maybe it would help me, getting them out of my head and down on paper. My next though is that it will be quite time-consuming. But the idea may be good? I must consider this.' (J6§2)

Investigating what one does implies that there may be other options. The point of view Joe presents implies that it may be possible to do things differently. This is an important point concerning the investigation of activities. The recording of the sessions shows that Jane gets the idea of putting her intrusive memories into writing, an idea that Joe supports. Jane also uses the journal to contemplate this option.

In this log, Jane also starts investigating the content of her memories. She notes,

'Many of my memories have some or other negative feeling attached to them and it grieves me that the good memories from my childhood, which do exist are somehow infiltrated by the bad ones. In a way, there are no memories that are exclusively nice to think about. As a rule there is a bad association attached, if I follow my train of thought a short way. For example, 'I can remember being at the funfair; the sun shining and having a go on the Big Dipper, while mum sat down the pub and wouldn't come home, even though it was late and we were tired' or 'it was fun being at Gran's; we drank PG tips and played Gin Rummy; apart from when I was sent to the store to buy more beer and whisky for grandpa, even though I didn't want to.' (J6\$2)

Jane seems to be developing ideas about why it is difficult for her to deal with her grief i.e. because it is all mixed up. The bad and the good stuff are intertwined.

\section{JOE'S THEORY OF GRIEF}

Jane continues her investigation in her next log,

'we hit a soft spot [ømt punkt] in the last session, it made quite an impression on me when Joe talked about my not being allowed to experience being childish and free from concern in my childhood as a matter of grief for me [lit. 
The Case of "J ane and J oe": A Diary-Based, Cross-Contextual Case Study

Mackrill

Pragmatic Case Studies in Psychotherapy, http://pcsp.libraries.rutgers.edu

Volume 7, Module 1, Article 11, pp. 187-229, 02-28-11 [copyright by author]

det var en sorg = it was a grief tm]. But then I don't quite know what to do with it? Grieve, I suppose? But I think I do, by sometimes getting sad and having conversations in my head with the people who hurt me. In the situations where pictures turn up of nasty incidents or situations where I was sad, I get to say the things I couldn't formulate as a child. For example how unfair it was, how frightened I was, and how much I wish things had been different. The grown ups who let me down in one way or another are also often told (still in these conversations in my head) that it was damn well wasn't right [at det sgu ikke var i orden] and they should be ashamed of themselves [det kunne de ikke være bekendt]. This is how I try to deal with these incidents, but I must admit, I just as often try to push the pictures away and think of something else.' (J6aß1)

Joe has presented the point of view that Jane's feelings are a matter of grief. He notes that grief involves 'putting into words' (Jt3§4, Jt6§6, Jt6§9). It also involves 'feeling the feelings' [at mærke følelserne] (Jt6§8), and it also involves the aforementioned need for expression (Jt3§4) and thereby reception and together this seems to make up what Joe calls 'living and feeling your way through it' [en sorg, der skal mærkes og gennemleves] (Jt6§8). This point of view involves the idea of going through a process, 'grieving' (Jt6§5) and that this can help you feel better, as Joe notes,

'my suggestion about viewing parts of one's feelings as grief seems to make sense to her and perhaps it 'makes it easier to survey [overskue] and accept what she senses [mærker]' (Jt6§5)

This a therapeutic goal, a concrete proposal Joe has, as to how to deal with Jane's sadness that she feels she experiences too much of. As the two prior quotations from Jane's log in this text show, Jane begins to use the term grief in her comprehension of her situation (J6§1, J6§2). Once again this shows how quickly therapeutic points of view are employed by Jane.

Joe is sensitive and critical about his own points of view, and assesses them, asking himself, 'if it is a help or will it be a hindrance?' (Jt6§8). Joe is sensitive to the dilemma Jane faces in confronting her grief, as we will see, he has good reason to be careful.

'In a way I think it is very good that Jane has sensed this feeling of grief since we spoke together last. If talking about grief due to a lost childhood makes sense: both what she lost and what she never got which remains something she longs for - then the feeling will naturally become clearer. In another way I am in doubt as to whether it was right to talk about grief, it makes it harder for her to bear.' (Jt7§8)

In the following session after Joe presents his point of view concerning grief, Jane notes the following in connection with the introduction of the point of view concerning grief,

'It has had an effect on me, as I have had times where I haven't been able to imagine I would succeed in anything, that I would fail miserably in all areas.' (J7§1)

Joe's point of view concerning the past and grief has according to Jane, brought about a sense hopelessness with regard to the future. The past seems to have engulfed her and she has at times lost all sight of a positive future. Entering the past is a challenge to Jane and she clearly needs support. Joe helps Jane by asking, where she sees herself in ten years time' (J7§1). Jane has no trouble answering this, noting,

'I must admit, the most pressing thing for me right now, or what I've thought most about, is whether I will succeed in having my own family. I've thought more and more about this the last couple of years and I more am ready to make it a priority than before.' (J7§1) 
The Case of "Jane and Joe": A Diary-Based, Cross-Contextual Case Study

Mackrill

Pragmatic Case Studies in Psychotherapy, http://pcsp.libraries.rutgers.edu

Volume 7, Module 1, Article 11, pp. 187-229, 02-28-11 [copyright by author]

Jane shifts her perspective from a focus on hopelessness, where any thought of a positive future has disappeared, to a focus on realising her hopes and dreams. Joe maintains this focus throughout the session where the topic is Jane's desire to establish a family of her own.

\section{REPRESENTING THE FUTURE}

I have previously shown how Jane sometimes does not focus on her subjective emotional state (I-focus). In these situations Joe sometimes vicariously focuses on what Jane's subjective emotional state might be. The above example shows how Jane similarly loses sight of the future from time to time. By asking Jane about the future and maintaining a focus on the future, Joe represents the point of view that Jane has a future, even if Jane looses sight of it from time to time. Joe comes to represent the point of view that there is hope. When Jane is engulfed by a sense of hopelessness Joe encourages Jane to talk about her aspirations (Jt3§3). Joe vicariously maintains the point of view that there is hope for Jane, even if she loses sight of it from time to time.

Jane also looses sight of the future when she is afraid that her family may suddenly die (J5§1). She does not imagine what her future would be like if they died. Jane notes,

'I have rather just seen pictures in my head of a funeral and people who are sad, me too.' (J5§1)

Joe challenges her to find out what it would be like if her mother was no longer with her. Jane says she would feel alone. However, Jane's investigation into death takes a new turn. She notes that if her mother died, she would be next in line and continuing on from this she notes

'I am not really concerned about my own death, only if I go and die before my mother or George [brother tm]. I can hardly bear the thought that they would not have me to look after them. At the same time, the thought of their grief is also almost too much for me. So I will just have to keep myself alive. (J5§1)

Here we can see an extremely clear example of a lack of I-focus. In her writing Jane quickly waylays the significance of her family's death on her and instead considers her mother and brother's future if she dies. Her own future if they should die is subordinate. The lack of an Ifocus and the lack of a future focus seem to be connected in this example. Once again Joe vicariously represents the point of view that Jane would have a future even if her family died. He represents hope. The important point here is to note that maintaining a point of view on the future is crucial in dealing with Jane's past. Otherwise the past has a tendency of engulfing her and she loses sight of the future. Thus dealing with the past and the future are intertwined. The future perspective is necessary in dealing with the past.

In connection with this example concerning Jane's fear of her family dying, Joe also presents a point of view concerning what is general for human beings. Jane notes,

'It was actually quite an eye-opener when Joe presented the idea that death is life condition that we all face and live with. Therefore believing that I am the only person who has frightening thoughts of this nature is perhaps a little pretentious.' (J5§1)

The whole issue of what is general for people and what is specific for particular groups is an area where Joe has many points of view. Joe's thoughts on grief are an example of this, as are his 
The Case of "Jane and Joe": A Diary-Based, Cross-Contextual Case Study

Mackrill

Pragmatic Case Studies in Psychotherapy, http://pcsp.libraries.rutgers.edu

Volume 7, Module 1, Article 11, pp. 187-229, 02-28-11 [copyright by author]

thoughts on sharing, which will be presented next. The specific example shows how Jane does not consider whether other people suffer in similar ways. Joe's stance takes this into consideration. Joe represents the point of view that Jane is one person among many people, with whom she shares similarities and differences. Jane viewed her suffering as an isolated phenomenon. She begins to see her suffering concerning her fear of her family dying as a general human phenomenon. This is another example of a different point of view that seems to have therapeutic significance.

\section{JOE'S THEORY OF SHARING}

Joe has a series of points of view concerning sharing. Joe's stance on grief is closely connected with his stance on sharing. Joe's theory of sharing is a challenge to Jane's point of view concerning keeping things to herself (J5§2, J12§2). Sharing with a man is an added challenge, as Jane has terrible experiences with trusting men. Joe pursues the idea that sharing is necessary to alleviate sadness. Jane considers Joe's theory of sharing, noting how he has pointed out the importance of

'telling what you see to another person, so you are not as alone as you were in the original situation you are recalling.’ (J1aß2)

Here Joe suggests the idea that the past can be experienced in another way if shared, as the new experience of the past involves an added sense of community rather than the previously experienced isolation. Joe's point of view concerning sharing has to do with what community can offer. Jane notes later in the same passage, that the other person can 'validate" what is said (J1a§3) and that telling another person may also be significant,

‘so I know that now another person knows what I know’ (J1a§3).

Joe refers to this as having a witness, which is a term Jane also adopts in her journal. Joe notes the significance of this stating in relation to the same session,

'I think in the long run, her not carrying this alone, but sharing it with someone, how it was and is now feeling it, has great significance.’ (Jt1§8).

So, according to Joe, sharing is not just a matter of telling someone else. It involves experiencing oneself doing this with someone. Joe also maintains that the witness' role also has to do with making the client feel that her experiences and the feelings in connection with these experiences are appreciated/acknowledged [anerkendt] (J8§1). Once again Joe is referring to the importance of the reception of what is said.

Joe presents new ideas on sharing throughout his log. For example, after the fifth session, Joe notes,

' I wonder if Jane has more of such thoughts, feelings and concerns, that she doesn't share with anyone. I am also thinking about a sense of belonging together [samhørighed] and intimacy [nærhed]. For me these are to do with being able to share much of what occupies me with others. How will I get these things without talking about what occupies me?' (Jt5§3). 
The Case of "Jane and Joe": A Diary-Based, Cross-Contextual Case Study

Mackrill

Pragmatic Case Studies in Psychotherapy, http://pcsp.libraries.rutgers.edu

Volume 7, Module 1, Article 11, pp. 187-229, 02-28-11 [copyright by author]

Joe thus refers to a sense of belonging and intimacy that sharing gives him, and that it might also offer Jane. He reflects on Jane's experiences in the light of his own experiences.

Later, Joe introduces words other than sharing. He writes about confiding in [betro sig til] - and being authentic towards (Jt11§5). Confiding involves both sharing but contains an aspect of putting your trust in someone. Thus for Joe, sharing involves trust.

Joe also mentions a point of view whereby sharing is seen as validation, once again in a very phenomenological way, noting

'... it makes a lot of sense: that Jane thinks something and feels something inside is real of course, but in a way it first becomes really real, when she shares it with someone else. I am sure this doesn't just count for the past, but also for things now. It has to do with coming out (and showing) yourself [at komme ud med sig selv] and going beyond yourself and into the world [komme ud over sig selv og ud i verden]. (Jt8§3).

This last section is a precise description of what Jane is doing. She is presenting her perspective of what happened to her as a child, which she has previously kept to herself and by doing this she shows herself. Jane also goes beyond herself by telling someone else. She surpasses her normal way of being, which involves first telling people things when she has is completely in the clear as to where she stands (J12§2). Joe questions Jane with regard to this, by asking her whether she keeps her memories to herself to maintain a sense of control over them, that she would fear losing if she shared them (J8§1). Jane thinks he has a point. Sharing would involve Jane giving up some sense of control of her experiences.

Joe also describes the idea here that sharing can change experience. Joe notes that experiences can go from being experienced as real, to being experienced as really real (Jt8§3). Jane describes something similar in the following passage after the same session, noting the advantages of sharing

'If I told someone about them [the memories tm] they would seem real in some way and I might feel that my experiences and the feelings I have in connection with them were appreciated/acknowledged [anerkendt] so they would no longer just be mine, but shared with someone, who can act as witness to the fact that it is true and that it was damn hard being Jane for a long while and it wasn't fair, that I had to go through those things.'(J8§1)

Joe writes about the importance of putting experience into words. (Jt3§4,Jt6§6,Jt10§17) There seems to be a connection between putting experiences into words and making them more real. We have seen plenty of examples of how Jane's points of view become real to here. Recall for example the many 'apparently's. Here is another example. Jane notes,

'The fact that I find being with men generally speaking slightly difficult shall no longer be a secret'. (J2§1)

What seems to be happening here is a shift from a 'tentative' grasp of something to a firmer grasp. Jane's point of view has become more real. Jane has mentioned her difficulty with men in her referral session and in her initial two logs (J1§4 \&J1a§7). This point of view is shifting from being a tentative point of view to a more accepted possible point of view. Whereas Joe writes about experiences going from 'real' to 'really real', Jane writes about how telling someone would make the memories 'seem real' (J8§1). Jane also expresses the point of view that writing 
The Case of "J ane and J oe": A Diary-Based, Cross-Contextual Case Study

Mackrill

Pragmatic Case Studies in Psychotherapy, http://pcsp.libraries.rutgers.edu

Volume 7, Module 1, Article 11, pp. 187-229, 02-28-11 [copyright by author]

about her experiences helps her to see them from the outside [udefra] (J8§10). Telling her stories to Joe is a way of validating them (J8§1). Even though Joe cannot know what actually happened to Jane, he knows that things like Jane has experienced do happen, as he has heard about such experiences many times before.

Jane considers sharing an 'unnatural' act i.e. it feels 'wrong'. It is something she has to force herself to do, as Joe notes,

'She also says she's not used to sharing her thoughts and feelings with others and...thinking about the possibility moves her. At the same time there is a barrier, that she has to force herself to do it' (Jt10§3)

Jane experiments with sharing with Joe even though it feels 'wrong'. Though Jane is sceptical initially, she experiences that it helps, as Joe writes,

'Jane has wondered why the old memories haven’t arisen since the last session - that our talking about it last time has apparently changed something. She has felt calmer which has been nice for her, but otherwise it hasn't been particularly significant. Once again she mentions that she is surprised that whether she thinks something through on her own, or whether she talks with someone else about things, makes a difference.' (Jt10§1-2)

She is experimenting with Joe's point of view that sharing helps. She tries it out. It works. She is still tentative.

As Joe writes his journal, he presents new ideas concerning sharing as these become significant during the course of the sessions. He gains access to new aspects of Jane's life as the therapy progresses. The intersubjective nature of therapy is extremely clear. His contact and possibilities for interacting with Jane are connected with how much she reveals and this for Jane involves going beyond herself, as she is concerned with brushing things aside and trying to forget. He is dealing with her problems together with her, but she can first talk about these problems, when she has moved beyond them, as talking about her problems demands moving beyond the problem of choosing isolation, just getting on with her life and being in control. The therapy constantly leads to therapist frustration, as he tries to get Jane to share with him, but she doesn't always want to share. It is something she has to force herself to do. For a long time, Jane can't see the point of it.

For Jane, the frustration involves wanting help to get rid of the sadness and being faced with Joe, who keeps reminding her of all the sad things by examining connections with the past. She increasingly experiences herself as someone who cannot forgive and forget and get on with her life. Joe would like to work with Jane so she can feel better, but he keeps feeling distanced from her, probably because there is a distance. Their points of view differ. At one level, they have a joint project. They both want Jane to feel better. At another, they don't. Joe rejects Jane's original problem-solving strategies completely and with good reason. They don't work. On the other hand, he cannot do this too openly for fear of her experiencing that she is being rejected as a person, which is the last thing he wants. He asks himself, is it too much? Will it just make her worse? Maybe I should have done it differently (Jt6§8, Jt7§8, Jt8§2, Jt12§10). This has to do with his extremely limited access to her situation and the immediate conflict in their positions. His sensitivity is extremely important. In this process Jane gradually becomes more aware of the hopelessness of her attempt to forget. 
The Case of "J ane and J oe": A Diary-Based, Cross-Contextual Case Study

Mackrill

Pragmatic Case Studies in Psychotherapy, http://pcsp.libraries.rutgers.edu

Volume 7, Module 1, Article 11, pp. 187-229, 02-28-11 [copyright by author]

We will now return to Jane's log after the seventh session, where she has just felt a sense of hopelessness and Joe has asked her about her hopes for the future. We return now to Jane's concern about 'finding a good man' and Jane notes a shift in her perspective on this.

\title{
FINDING A GOOD MAN - INVESTIGATING MORE TOPICS
}

\begin{abstract}
'Previously I wanted a boyfriend as it might be nice [fordi det da sikkert kunne være meget hyggeligt] having someone to visit, when my girlfriends were busy, or with their boyfriends. Today I think I connect having a boyfriend with having a secure base for a family. It's not because I have a burning desire to have children right now, but rather, as I've said, to have someone to share my life with, love and be loved.' (J7§1)

The shift that Jane describes is from having a man as a way of passing the time, when girlfriends are not accessible, to having a man as a 'secure base for a family' and 'someone to share her life with'. There is a shift here from seeing a man as a pastime to seeing a man as a secure base and a life companion. Following on from this Jane notes her desire to love and be loved, which she hasn't mentioned previously, even though she says she has. Jane now introduces a new view of men, noting,
\end{abstract}

'this brought us to the subject of my scepticism, as to whether I will succeed in reeling a man in [lit. at få halet en mand indenbords = hauling a man on board] $(\mathrm{J} 7 \S 1)$

Thus Jane shows her point of view that a man is something that can be caught like a fish. Joe presents a different point of view that Jane describes in the following way,

'... maybe attraction between two people happens at an unconscious level and perhaps I only have to walk through a doorway to have aroused someone else's interest. If this is the case, I don't need to feel I have to make such an effort by both communicating all my fantastic qualities [which can make me feel insecure if I don't succeed) and by feeling I have to be on the look out [opsøgende] (which I am neither particularly good at, nor do I particularly want to). Maybe my next boyfriend will find me, without my having to go to so much damn trouble. The thought is definitely nice. (J7§2)

There is also another basic difference in point of view here. Jane presents a point of view built on the premise that men can be controlled and reeled in. Joe on the other hand presents a point of view, that matters of love are beyond control, it just happens when you walk through a door. This is a major difference in point of view. Once again here we can see Jane using her journal to reflect on Joe's points of view. Jane also investigates one of her own points of view.

'I often find being in male company slightly difficult, especially if it's a man that I feel is superior to me. However if I feel I am superior to him, that is if I am cleverer or better looking than he is, then it’s some how easier.' (J7§1)

Jane uses the log to increase her awareness of her own points of view, as shown above. She finds being in relationships difficult unless she sees herself as 'one up' on her partner. This is clearly a subject that has been considered in the session, as Joe notes,

'Maybe I'm wrong, when I sense an insecurity and fear of losing control by giving herself to something (give sig hen til noget), which would be very painful to loose again. But that is what I am thinking about. And there is something to do with the word and concept of 'giving yourself to' [hengivelse] which keeps coming back to me with regards to Jane. In a way it is strange; she is very open but then there seems to be a distance with respect to saying, 
for example, you are important to me, or something like that. But it is slightly flighty or unclear to me. I don't think I have understood it.' (Jt7§9)

Joe has the impression that Jane holds herself back. That she does not like to let others become significant, and she does this to stay in control. Joe wonders whether Jane has ever been in love. He notes,

'First Jane is not sure if she has ever been in love. Later she remembers a young man she met during a stay at a school, who she fell very much in love with. To cut a long story short, she became so unsure of herself, flustered and ended up feeling so lousy being near him, that she withdrew from him completely. (Jt7§4)

Jane notes something similar,

'I have a tendency to simply remove myself from any potentially dangerous situation with a man, as I don't know how to deal with it.’ (J7§1)

When Jane investigates her points of view concerning men and relationships, it becomes clear that Jane has avoided relationships that involve her losing control or giving in to passion. Joe is aware of this, noting,

'The whole spectrum of 'giving yourself to' [hengivelse] and being loved for the one she is, ( $\ldots$ are things she only faintly knows.’ (Jt7§7)

Joe presents Jane with a point of view that might enable her to grasp and deal with her ambivalence in relation to men. Jane notes,

'We reached the conclusion that the reason I can become frightfully nervous and unsure of myself stems from the teenage girl inside me, who didn't have the energy to have teenage experiences with boys. At that time I both had to deal with the insecurity of my family situation and pay attention to my mother's needs and then I also had to figure a lot of things about how boys and girls are together and become friends or couples...(....) I find accepting this insecurity that I have very difficult as it doesn't correspond with the picture I have of myself in many other areas. But it's part of me, and I might be able help the teenage girl in the situations she finds difficult by reassuring her and trying to feel ok being in those situations. Keeping a hold of the fact that it's not dangerous and it is ok to be nervous and unsure. (J7§1)

Jane has found her feelings of insecurity difficult to deal with. These feelings do not correspond with how she sees herself. Joe introduces the idea of a dual perspective, suggesting that Jane experiences meeting men as an inexperienced teenager and as an adult. He suggests these two points of view do not correspond and they co-exist. Clearly Jane's strategy has been to try and deny one of the points of view, 'that she is insecure'. Jane clearly has difficulty identifying with her insecurity referring to this in the third person as 'the teenage girl', a term that Joe has introduced. Joe's point of view about a possible dual perspective strikes a chord with Jane, who can clearly see potential in this point of view and in the idea of 'helping' and 'reassuring' the ‘teenage girl' i.e. herself.

The idea of the dual perspective may be so well received by Jane as it has phenomenological validity. If we investigate the traumatic material presented by Jane in her journal, we can see how Jane switches from the past tense (the adult perspective looking back at her childhood) to 
The Case of "J ane and J oe": A Diary-Based, Cross-Contextual Case Study

Mackrill

Pragmatic Case Studies in Psychotherapy, http://pcsp.libraries.rutgers.edu

Volume 7, Module 1, Article 11, pp. 187-229, 02-28-11 [copyright by author]

the present tense (the child's perspective, experiencing the traumatic event). Let me exemplify this by taking examples form Jane's journal,

'I must have been $11 \ldots(. .$.$) I can definitely hear my mother being hurt in some way or other. I am lying down and$ am wide awake and I just don’t want to go in and see what's going on, afraid of what I will see’ (J8§2)

'Another incident that happened during the time we lived in S town, was one evening when my mum went to town...(...) as she gets closer I can see she is yellow and blue, bloody and her face is puffed up'. (J8§3)

'I must have been 5 and we had just moved away from my Dad...(...) I can definitely see my mother lying on her stomach in my aunt's bed with one of her arms hanging over the side' (J8a§2)

'When I was 14, we lived in X town...(...) I am standing up on the roof and through the hole in the roof, I can see my mother lying lifeless on the ground. People are crowding round and I can hear someone shout that the people should move, so she can get some air. (J8aß3)

There is clearly a phenomenological correctness to the dual perspective. Jane moves between two perspectives in her writing, represented by the two tenses. The adult perspective looks back in the past tense and the child perspective experiences in the present tense. Both perspectives are, of course, Jane's. Joe's appreciation of this gives Jane a sense of acceptance of what she is experiencing. The point of view concerning a dual perspective offers a way of understanding her situation without implying there is something 'wrong' with her. As we will see later, Jane uses the point of view concerning a dual perspective on the past to understand and deal with traumatic memories, just as she here explores the idea of using the dual perspective as a way of supporting herself, or 'helping the teenage girl', as she calls it.

Thus Jane becomes aware of the point of view that she practises towards the past. She is developing her understanding of her problems. Jane's investigation of how she deals with the past continues in later logs, she notes

'I think I spend a lot of time rationalising after the event by in my head thinking situations through again and again. If it is an uncomfortable situation, I can, in my head, say the things I didn't actually say, or take the discussion that I didn't have the courage to take, when I stood in the situation. If it is a good situation, I think a lot what was good about it and what it makes me feel. In connection with the childhood pictures that usually turn up in my memory and make me sad, I do the same. [I] think an enormous amount about how the details of the situation were and [I] look at it with 'adult eyes'. Afterwards I can again as an adult tell the people who hurt me or disappointed me off, sometimes while the child 'watches'. This is, I suppose, a way of looking after the child who had to experience these things that made her sad.' (J7a§1)

Jane is processing the past in a new way and reflecting on how she does this. She is again using the point of view that Joe has previously introduced concerning a dual perspective on the past. This point of view offers Jane a way of comprehending her experience incorporating her experience of being insecure sometimes and also being a capable adult. The section clearly shows how Jane uses this dual perspective to understand and deal with her situation.

Jane has continued her search for a way of dealing with her intrusive memories. She finds an alternative to pushing her memories into the background. She begins to support herself or 'looking after the child', as she calls it. She notes details of the method, the use of 'adult eyes', letting the 'child watch', telling off. In a way she is reviewing and reliving her life from her 
The Case of "J ane and J oe": A Diary-Based, Cross-Contextual Case Study

Mackrill

Pragmatic Case Studies in Psychotherapy, http://pcsp.libraries.rutgers.edu

Volume 7, Module 1, Article 11, pp. 187-229, 02-28-11 [copyright by author]

present 'adult perspective, the life she lived as a child. There is a striking correspondence her with Joe's phrase concerning grief where he writes about 'living your way through it' (Jt6§8).

A shift takes place here, a shift in focus from 'not being afraid' to 'how to be afraid'. With this point of view Jane has found a way of understanding and caring for herself. The dual perspective offers Jane a way of accepting her fear without loosing her sense of authority.

Joe also introduces the dual perspective when Jane contemplates her relationship with her mother. He supports Jane in having realistic expectations towards her mother who has been a substance abuser practically all her life. Thus Joe notes they,

'talked a bit about hoping (rather like a child) and wishing for something without putting your life on the line [uden at lægge sit liv an pa det]. I'm not sure she understood what I meant by the difference.'(Jt11§2)

Here Joe again works with a dual perspective. Suggesting there are two different points of view that can be taken. One can hope one's mother's condition will improve, rather like a child, where it feels like your life depends on it. Or one can take an adult perspective and 'wish' one's mother would get better, well aware that her not getting better is not the end of the world. This point of view is a challenge to many adult children of alcoholics (ACOA). Often they see their choice as one between making their parents totally significant (constantly attending to them) or insignificant (choosing not to see them at all). Many ACOAs feel compelled to take one of these positions. Joe is offering a third possible perspective. I will not discuss this difference in points of view here, as Jane does not pick up on it in her journal. However mentioning it is necessary as this point of view is central to Joe's understanding of ACOAs and the treatment of their problems. After reading Joe's diary, Jane tells him, she did understand what he meant by this and she has been aware of this difference in possible perspective towards her mother for quite a while.

\section{BEARING A GRUDGE}

Jane's dealing with the past also involves another element. Jane is concerned as to whether telling people off in the past is the same as

'...bearing a grudge? I actually think I have loads of grudges, not just from my childhood, but also from old relationships. Even here I can recall old experiences and up in my head tell them off or tell them what I want, depending on the situation. It would be great if I found it easier to let go of these things that keep turning up. Something like 'forgive and forget' ['forgive and forget' is written in English. tm] and get on with it. But it seems as if I am stuck in these experiences and it vexes me that it was as it was. (If only I had acted in a different way, done, said something different. Then things would have been different). Isn't that bearing a grudge?' (J7a§1)

Jane's investigation of her feelings is sometimes far removed from Joe's point of view concerning grief. Jane presents the point of view that being sad about the past and telling people off for things they did may also be viewed 'bearing a grudge'. This involves the point of view that remembering bad things in the past is wrong, where forgiving would be right. There is a clear difference in point of view here. The term 'bearing a grudge [bære nag] is derogatory. Once again Jane is condemning herself and her own feelings. She presents the point of view that she shouldn't have ill-feelings but instead forgive and forget or accept and get on with her life. Once 
The Case of "Jane and Joe": A Diary-Based, Cross-Contextual Case Study

Mackrill

Pragmatic Case Studies in Psychotherapy, http://pcsp.libraries.rutgers.edu

Volume 7, Module 1, Article 11, pp. 187-229, 02-28-11 [copyright by author]

again Jane tries to find some alternative ways of dealing with her situation. But this doesn't work for her. She blames herself for not having behaved differently in her past. But this, of course, is not something she can do anything about now and there probably wasn't much she could have done about her situation then.

\section{THE SLUICES OPEN}

It is first after most of the points of view presented so far in this paper have been considered, that a flood of traumatic memories appear, or to use Jane's words, the 'sluice' (J8a§1) opens (see descriptions of traumatic events in J8, J8a, J9, J9a, J10). This may suggest that Jane's possibilities determine what she experiences. Jane now has a way of dealing with her memories. She isn't occupied by other factors in her life and she has temporarily suspended trying to forget. A shift takes place and the 'sluices' open. Jane finds the therapy sessions a suitable place to talk and cry, writing

'these aren't topics you just happen to discuss at breakfast and this makes it slightly difficult to find an occasion to tell other people about them.' (J8§1)

Jane has a point here. Where do you slip into casual conversation, that you watched your mother being raped with a bottle at the age of 11 . The emotions are decontextualised in the present but contextualised in the past. The therapeutic room acts as a special context, a context for the decontextualised past. Jane has not previously spoken to anyone about these incidents.

Jane also notes other problems in dealing with traumatic material. Once she starts focusing on traumatic material in her consciousness it if she has opened a 'sluice'. She monitors this material in three consecutive logs,

'By the way, it feels as if the sluices have been opened regarding the pictures played out on my inner screen. As if there are more of them and they come and go at a speed, which has increased significantly.' (J8a§1)

'It is as if there is more calm on my inner film, since I was last in to talk to Joe and tell him about some of the incidents that turn up again and again. Actually, it's not that they don't turn up, but they have in some way not affected me as much as the previous ones. By the way, I could also feel a difference in my stomach between before and after I was in there last time. Before our conversation I felt uncomfortable in a way and had butterflies in my stomach in a tense way, and I haven't really had that since. (J9§1)

'As I wrote earlier, my inner film has actually been fairly calm. I haven't had problems falling asleep and it is often in these situations that a lot of pictures and incidents pop up. But I haven't really felt anything since I last spoke to Joe.’ (J9a§1)

Jane uses the journal to monitor the process of opening the 'sluices'. She uses Joe as a support. This time she does not become engulfed by the past but regulates them.

'I can now sense how one story leads onto the next now, so I will take a break here.' (J8§6)

Joe seems to have presented Jane with a series of points of view that make dealing with the past possible. The journals show how Jane at a certain point (shift) adopts a new stance and gives up trying to forget. 


\section{THE MEN IN JANE'S PAST}

In this case history, I want to offer readers an impression of the trauma in Jane's past as she presents it in her journal. I will do this in this section. As I have noted, Jane keeps returning to the theme of finding a good man, and Joe investigates the connection between past and present contexts. After the tenth session, Jane writes,

'We talked a bit about where this mistrust comes from and the obvious answer is, of course, that it is something I learned at home...(...) My mum always presented boyfriends who couldn't be role models for anything. On the contrary, there was usually more unrest and instability when she had boyfriends than when we were just us' (J10§1).

Jane has in previous sessions given many examples of this ‘unrest and instability’. For example,

I must have been 11 years old. My mother's boyfriend Pat, was a psychopath, drank copiously, and was completely out of control. One evening I lay in my bed and couldn't sleep, because I could sense something was going on in the living room that wasn't good. I can't remember what happened earlier in the evening, there had probably been drinking and quarrelling. I can definitely hear my mother being hurt in some way. I am lying wide awake and don't want to go in and see what is happening at all, afraid of what I will see. On the other hand, I don't like staying in bed, if it is so serious that she needs help. Slowly I walk to the door between the living room and my room, I am shit scared and can hardly feel the floor under me. When I step into the living room I can see them both rummaging on the sofa, her below, him leaning over her busy raping her with a bloody wine bottle. It looks really violent and the noises are indescribable. I was completely dismayed, shocked and incapable of saying anything. My body wanted to scream that he should stop, but my stomach contracted and became one big knot and the only thing that came out was a strange sound before I turned and ran towards my room. By then my mother had seen me, which made her shout louder that he should stop. She must have shaken him off as shortly afterwards she came into my room and I think she said something like it wasn’t serious. But I could both see and hear it was. (J8§2)

'Ok, I can feel I am not quite finished with Pat. He was in every way a nasty, violent, drunken man, who was completely out of control. Thank God I was at the children's home most of the time my mother was with him, so there are many things I have only been told about. e.g. when he tied my mother to a radiator and beat her with a vacuum cleaner pipe, or when he cut her hair while she lay asleep.' (J8\$7)

Jane also refers to an incident with another of her mother's boy friends, Richard, an artist.

'One day, the same Richard, during a row with my mother, threw a knife through the living room at her. She just managed to take cover by closing the door to my room behind her so the knife landed in the door frame instead of where her shoulder blade had been a second earlier.' (J8§5)

Clearly Jane has childhood experiences of boyfriends being extremely violent and out and control. She also has experiences of being abandoned by men and feeling let down by her mother. One of these experiences has previously been mentioned (see page 200), where Jane's mother sends her off with a man to buy drugs. Jane also has another intrusive memory regarding the aforementioned boyfriend Richard,

'He accused me one day of stealing 10 dollars which had been lying on a dresser. The money had to be handed back so he could buy beer. My mother has always trusted me a lot. In spite of the fact that she never previously had had reason not to trust me, she suddenly leant towards believing Richard, when he claimed I had taken the money. I have never before felt as unjustly treated, as when I had to face the accusation that I had stolen. I have damn well always been Miss Trustworthy herself, [jeg har sgu altid været troværdigheden selv.] Later the money was found behind the dresser it had been lying on. It had just fallen off. I am not sure I was given an apology.' (J8§4) 
Jane also experienced being let down by a social worker [pædagog], an experience that has been presented earlier in this text. He was the only man she ever trusted, and he ended up falling in love with her and telling her this, despite a massive age difference and her viewing her relationship to him as paternal. This left her feeling 'disgusted', 'frightened', 'stabbed in the back' and 'betrayed' (J10§1). Jane notes that after this experience she stopped believing that men have legitimate intentions. She felt that men always have a hidden sexual agenda. To quote Jane,

'Actually I think (in consultation with Joe) that this feeling of not being able to trust what men say completely, has been with me since then. An ingrown belief that men's intentions aren't honest [lit. reel]; that they may say one thing, but they mean something else. This is the reason why I don't have many male friends. I just don't believe they want to be friends, so I probably behave slightly suspiciously and not in such a relaxed way, as I maybe unconsciously am sitting and waiting for them to 'get to the point' and reveal what they are really up to. Based on this, it is perhaps hardly surprising if I find being together with men slightly stressful!!’ (J10§2)

In consultation with Joe, Jane examines the significance of the past in her present. Once again we can see how she tries this point of view out. She starts out being tentative, writing 'I think'. Then she shows resolution in her 'this is the reason', and Jane ends up once again tentatively with a 'perhaps'. She is beginning to become aware of her point of view and its contextual basis, her point of view being,

'Basically, I don't trust men to take real responsibility for me in my life, probably because I am used to being completely independent of men (boyfriends) and I am used to being able to do everything myself, and doing everything myself. In other words, I have stopped trusting that a man will show genuine interest in me in any real way and take responsibility for a relationship. It is my expectation that I just sort of take over and am the one who watches out [passe på] and protects, because this is a role I know well and it is easy for me to fall right into it, even if it is not where I want to be.' (J10§1)

\section{DISENTANGLING THE GOOD AND THE BAD STUFF}

After Jane has spoken to Joe and written about a series of traumatic events, (J8, J8a, J9a, J10) Jane experiences feelings of compassion for her mother in a new and powerful way. Joe also describes how Jane is moved in a new way (Jt10§6). Jane notes,

'My brother and I, in spite of everything that has happened have never doubted our mother's love for us. In some way she has managed to communicate to us that none of what happened was our fault and there was nothing we could do to change it. It was her responsibility entirely. Things went wrong due to her inadequacy. I have heard her say more than once that she wouldn't be alive if it hadn't been for George and I and if her costly experiences could in some way 'save' us from making the same mistakes, it would all have been worth while. I am not in the least doubt that she at any time would do everything in her power to help or support us in the choices we now make. Her love for us is unconditional and she hasn't just told us so, she has also emphasised that whatever happens or whatever we get messed up in, we could always come home. Admittedly, home wasn't always a place one wanted to be, but knowing there was always a certain amount of love one could count on, and that someone was ready to fight for you if necessary, I think, has been irreplaceable for me and my brother and I think we would be less tolerant people today, if this wasn't the case. It has been a nice ballast to have from home, the knowledge that she would never let go of us, or judge us for the mistakes we might make.' (J9§2-3)

A shift seems to have taken place. Where Jane previously noted that the good and the bad memories were mixed up. Jane is now beginning to separate the emotions connected with them. She has remembered a lot of the bad stuff and now she begins to remember the good stuff. In a way we can see the distinction Joe presented to Jane earlier between being 'touched in her heart' 
The Case of "Jane and Joe": A Diary-Based, Cross-Contextual Case Study

Mackrill

Pragmatic Case Studies in Psychotherapy, http://pcsp.libraries.rutgers.edu

Volume 7, Module 1, Article 11, pp. 187-229, 02-28-11 [copyright by author]

and 'sad about being let down in the past' (Jt3§11). Jane lets herself both grieve and be touched. This does not make her oblivious to the problems that exist in relation to her mother.

Joe validates Jane's positive view of her mother. He asks himself whether Jane by describing her mother in this positive light is in denial, which is, as he notes, common in families with substance abuse (Jt9§7) i.e. he asks himself whether Jane is fantasising that her mother loves her. Joe assesses Jane's feelings and concludes that they are authentic (Jt9§9). Joe notes how Jane is moved by strong feelings of love as she talks about her mother's love, thereafter he quotes Jane as saying,

'I may not have to be the only person who takes care of me' (Jt10§6)

There seems to be an interesting phenomenon here. When Jane talks about her mother's love, she becomes extremely moved. Experiencing the fact that her mother loves her (against so many odds, and even though this love is often highly problematic) seems to bring Jane to a stance that there might be other love for her in the world. This example shows how Jane, by telling the sad stuff, also begins to focus on the good stuff. What is clearly happening is that Jane is beginning to disentangle the good and the bad experiences in her past. After she has sensed the painful memories and grieved, the good bits are also revealed and Jane begins to consider that there might be good stuff for her in the future.

\section{BACK TO INTIMATE RELATIONSHIPS}

Joe presents more points of view concerning relationships and love during the later sessions. For example, he writes about

'a conversation about giving and receiving love as two important sides of love's essence. I also touch on the fact that she presently cheats herself of being filled up with someone else's love and care, and [we talk about] the change this will create in her and for her - and that it will make her far better equipped to deal with situations where she expresses a need, but it is not fulfilled' (Jt12§2)

Here Joe attempts to make some of the advantages of receiving love clear to Jane. Joe also becomes far more explicit in his assessment of Jane’s situation, noting

'She longs for a relationship. Put rather bluntly, I don't think it is possible unless she lets someone into her life in a way she hasn't yet tried and she risks becoming more dependent - so there is a more organic balance between dependency and independency.' (Jt12§6)

Joe's ideas of dependency are also related to another concept, a concept that has been presented earlier, the notion of 'giving yourself to' [hengivelse] (Jt7§7). Joe has the impression that Jane holds herself back, that she does not like to let others become significant, and she does this to stay in control. Joe presents the point of view that letting yourself be filled by someone else's love and care in one context can strengthen you. By making herself vulnerable in one situation where she receives love and support, Joe presents the point of view that Jane may become less vulnerable in others contexts, where her needs are not met. This point of view is a premise in the practise of psychotherapy. As we have seen earlier, Jane has previously emphasised the risk involved in trusting someone (J4§6). 
Joe seems to think Jane's point of view is shifting,

'She used to think needing someone and expressing this in the relationship was the same as placing your happiness in someone else's hands. And that means loosing your independence (....) She hasn't previously thought about this theme in this way - before she has been independent and giving in her relationships in a more automatic way, without sharing her heart of hearts [sit eget inderste]. (J12§2)

Jane considers the points of view Joe presents. In Jane's penultimate log (J12), she clearly expresses the dilemma, she faces. A dilemma that has become increasingly apparent as the therapy has progressed. Jane describes herself as caught between two points of view. She now connects this with her role in her family. Jane notes that her family views her as,

'the clever one, the strong one, who always has excess energy to help or mediate between family members, [this view] would fall apart if I said I needed help to get over my childhood. I seem to feel the role gives me a certain status and even though I often think it is hard and I would actually often like to be without this great responsibility of taking care of everyone else's well-being, there's probably part of me that finds letting go of this difficult. In this way I can see I play a part in presenting and enhancing the image of myself as the eternal problem solver, but maybe I don't quite know what alternative role I should play. On the one hand, I get a lot of praise and recognition for being the clever and strong one, but at the same time I don't think the role gives the image of a whole person, who also gets sad and needs taking care of now and again. This probably makes asking for and receiving care slightly harder, even though I feel this is what I need. I often neglect this need in relation to other people, with an 'I can do it myself' and maybe this has to do with a fear of becoming dependent on others' care. Perhaps this has to do with the fact that, if you are dependent on other people, then you can get disappointed and it is possible that my experience tells me, that I probably will be, and therefore I don't take the chance, trusting that people won't disappoint me and ask for the help I need. (J12§2)

Jane's dilemma is extremely clear here. She wants to ask for help and care, but she is not ready to risk being disappointed. Nor is she ready to risk her position in the family as the 'clever' and 'strong' one. As Jane sees it, she has a lot to lose by adopting a point of view that involves receiving care and help. However the two possible points of view are now clear to Jane, and we can see through the course of the therapy, how Jane begins to choose between concrete points of view in different situations. For example, Jane chooses to share her concerns about her mother with her brother, and she chooses to keep the fact that she is in therapy to herself. She chooses to tell Joe about her traumatic experiences, and she talks with a friend about her troubles with relationships. Jane's awareness of her dilemma confronts her with the existence of options, which she begins to grasp. Awareness of the generalisation gives Jane space to make exceptions. This is a description of a therapeutic shift. It shows how such shifts can occur.

\title{
I AM NOT THE SAME AS YOU
}

\author{
After writing about her mother’s love for her (J9§2-3), Jane makes yet another discovery. Jane \\ notes,
}

'I am slightly bewildered by the fact that I feel sorry for her, because actually, our backgrounds are rather similar. We have both grown up with alcoholic and drug abusing parents and we were both put into care. In many ways our being let down and doing without, must feel similar. In connection with this, we talked about why we have developed so differently, considering the fact that the conditions of our upbringing are similar in so many ways. (J9§2) 
The Case of "J ane and J oe": A Diary-Based, Cross-Contextual Case Study

Mackrill

Pragmatic Case Studies in Psychotherapy, http://pcsp.libraries.rutgers.edu

Volume 7, Module 1, Article 11, pp. 187-229, 02-28-11 [copyright by author]

Jane makes sense of how she is different from her mother. As mentioned one of the main reasons Jane entered therapy was to avoid having to take the antidepressants, the neurologist offered her (J5a§2). By not taking antidepressants, Jane proves to herself that she is not like her mother. Knowing you are different from your drug-abusing parent seems to be an important shift for ACOA's in therapy.

\section{UNDERSTANDING A LIFE WITH ALCOHOL AND DRUGS}

Joe also offers Jane points of view concerning life with alcohol and drugs. During the course of treatment, Jane's mother has a relapse and takes some form of drug again. Jane reflects on how her mother's behaviour challenges her points of view. Jane describes shifts in her points of view.

'There is something else I have to face up to. My mother is completely blind with regard to what her drinking and drugs does to her children. She simply refuses to see that seeing her like that makes us sad, that we are scared stiff of losing her and we are infinitely disappointed that she doesn't learn from the past. In return, she thinks we are hysterical and overreact, when we tell her we are scared that she might go and die on us ("Take it easy. It was only one pill. There's no need to get excited”, etc.) It hurts, but I really don’t think it will ever change.'(J11§4)

'I also have to face the fact that it damn well won't change, that I suddenly and without warning will be cast back into my childhood traumas by my mother's drug and alcohol abuse and be forced to make decisions about things that I don't want to deal with. I must face the fact that she will probably always be unstable in some regard or other and thinking 'now everything's fine' can be dangerous, as it can quickly turn.'(J11§4)

Joe presents the point of view, that it is normal for substance abusers to refuse to face up to the consequences that their abuse has on the people who love them. Joe also explains his point of view,

'An admission of this nature would involve taking responsibility for the damage one has caused and for many this can be a feat with unforeseeable repercussions. I think this is also why my mother's memory seems to be getting more and more selective as the years go by and I can clearly sense that she ignores her own responsibility for things going wrong.' (J11§5)

Jane uses Joes point of view to validate and develop her own. Jane highlights the chronic nature of her mother's condition. Her mother probably won't change. In doing this Jane also faces the chronic nature of her own situation. Her mother will probably always be like this. Jane notes a shift that has taken place earlier in her life. She refers to the time,

‘when I thought I could do something about my mum’s substance abuse’ (J11§3)

When her mother takes a drug again, Jane gets this feeling 'here we go again' (J11§1) and she has to process the fact that she cannot help again. She is powerless. She does this in her journal for example when she considers having her mother sectioned (J11§3). We can see here a shift that has taken place earlier, but, as is apparent, even though the shift has taken place, Jane has to confirm her point of view in this new situation. She reminds herself of her dilemma,

'honestly, I don't know what I would do. I can't sit on her or constantly make sure she behaves properly. On the other hand, I can't stand just standing in the wings watching her continue to spiral down, either.' (J11§3) 
The Case of "Jane and Joe": A Diary-Based, Cross-Contextual Case Study

Mackrill

Pragmatic Case Studies in Psychotherapy, http://pcsp.libraries.rutgers.edu

Volume 7, Module 1, Article 11, pp. 187-229, 02-28-11 [copyright by author]

Joe supports Jane in developing a realistic point of view towards to her mother. He sees confronting her with reality as an important part of his job,

'even if it can be hard, keeping this realism in her face [lit. op foran øjnerne = in front of her eyes] all the time.' (Jt11§4)

Just as Jane struggles to remind herself of her powerlessness in relation to her mother's problems, Joe finds it 'hard' too. Some points of view are hard to maintain and Jane has too keep reminding herself of her powerlessness and Joe supports her in doing this.

\section{VALIDATION}

As I have noted Jane and Joe were asked to validate a draft of this analysis. Jane only commented on one area where she felt misinterpreted, otherwise she found reading the analysis 'very interesting and rather educative [lærerigt]'. Jane's comment has been incorporated into this text. Joe also found the analysis interesting and he did not feel misinterpreted.

\section{REFERENCES}

Dreier, O. (2008) Psychotherapy and everyday life. London: Cambridge University Press. Mackrill, T. (2008) The Therapy Journal Project: A cross-contextual qualitative diary study of psychotherapy with adult children of alcoholics. PhD Dissertation. Copenhagen: Institute for Psychology, Copenhagen University.

Mackrill, T. (2011). A diary-based, cross-contextual case study methodology:

Background for the case of "Jane and Joe." Pragmatic Case Studies in Psychotherapy, 7(1), Article 10, 156-186. Available: http://hdl.rutgers.edu/1782.1/pcsp_journal 